\title{
Natural Polymers for Organ 3D Bioprinting
}

\author{
Fan Liu ${ }^{1,2}$, Qiuhong Chen ${ }^{1}$, Chen Liu ${ }^{1}$, Qiang Ao ${ }^{1}$, Xiaohong Tian ${ }^{1}$, Jun Fan ${ }^{1}$, Hao Tong ${ }^{1}$ \\ and Xiaohong Wang ${ }^{1,3, *}$ \\ 1 Department of Tissue Engineering, Center of 3D Printing \& Organ Manufacturing, School of Fundamental \\ Sciences, China Medical University (CMU), No. 77 Puhe Road, Shenyang North New Area, \\ Shenyang 110122, China; liufan-sky@163.com (F.L.); qhchen@cmu.edu.cnm (Q.C.); \\ 18856152351@163.com (C.L.); aoqiang00@163.com (Q.A.); xhtian@cmu.edu.cn (X.T.); \\ jfan@cmu.edu.cn (J.F.); tongh007@163.com (H.T.) \\ 2 Department of Orthodontics, School of Stomatology, China Medical University, \\ No.117 North Nanjing Street, Shenyang 110003, China \\ 3 Center of Organ Manufacturing, Department of Mechanical Engineering, Tsinghua University, \\ Beijing 100084, China \\ * Correspondence: wangxiaohong@tsinghua.edu.cn; Tel.: +86-24-31900983; Fax: +86-24-31900983
}

Received: 18 September 2018; Accepted: 19 October 2018; Published: 16 November 2018

\begin{abstract}
Three-dimensional (3D) bioprinting, known as a promising technology for bioartificial organ manufacturing, has provided unprecedented versatility to manipulate cells and other biomaterials with precise control their locations in space. Over the last decade, a number of 3D bioprinting technologies have been explored. Natural polymers have played a central role in supporting the cellular and biomolecular activities before, during and after the 3D bioprinting processes. These polymers have been widely used as effective cell-loading hydrogels for homogeneous/heterogeneous tissue/organ formation, hierarchical vascular/neural/lymphatic network construction, as well as multiple biological/biochemial/physiological/biomedical/pathological functionality realization. This review aims to cover recent progress in natural polymers for bioartificial organ $3 \mathrm{D}$ bioprinting. It is structured as introducing the important properties of 3D printable natural polymers, successful models of 3D tissue/organ construction and typical technologies for bioartificial organ 3D bioprinting.
\end{abstract}

Keywords: 3D bioprinting; natural polymers; rapid prototyping (RP); organ manufacturing; implantable bioartificial organs; regenerative medicine

\section{Introduction}

An organ is a collection of multiple tissues with particular physiological functions. The human body is made of about 80 organs according to a classification principle [1]. Each of the organs performs very important physiological functions. At present, the only effective therapy for organ deformity/defect/failure is through allograft transplantation. However, the severe donor organ shortages, the long-term treatment of immunosuppressive drugs, the life-long side effects of immune complications, and the extremely high costs of donor organs, have greatly limited its clinical applications [2].

There is an increasing demand for manufacturing bioartificial organs to repair/replace/restore the damaged/deformed/failed organs. This demand is enormous for all types of organs, but especially for the visceral organs, such as the liver, heart, kidney, lung, and stomach, related to chronic and acute failures [3,4]. A typical example is that in the United States of America the treatment of organ failures involves 34 million surgical procedures per year with less than one tenth of donors [5]. Only in 2013, there were 117,040 patients in this country who needed organ transplantation with near 28,053 suitable organs available [6]. 
The serious shortage in organ donor supply, together with the side effects of allograft rejections and extremely high costs of donor organs with respect to allograft organ transplantation has fueled numerous strategies for organ manufacturing over the last several decades [7-11]. Organ manufacturing is an interdisciplinary field that needs to integrate a large scope of talents, such as biology, materials, chemistry, physics, mechanics, informatics, computers, and medicine, to design and build bioartificial organs with essential multiple cell types, hierarchical vascular/neural/lympatic networks, heterogenous extracellular matrices (ECMs), and expected biological/biochemical/physiological functions [12-14].

Recently, three-dimensional (3D) bioprinting, also named as rapid prototyping (RP), additive manufacturing (AM), and solid freeform manufacturing (SFM), technologies have emerged as a promise way to produce bioartificial organs through an automatic layer-by-layer deposition method [15-17]. The most obvious characteristic of 3D bioprinting technologies is to print living cells together with polymeric hydrogels and/or other bioactive agents as 'bioinks' under the instructions of computer-aided design (CAD) models. Multiple cell types can be encapsulated in different polymeric hydrogels and deposited (or delivered) simultaneously.

Polymeric hydrogels are 3D hydrophilic networks which can absorb and retain large amount of water and gel under certain biological/physical/chemical and/or biochemical/physiological/pathological conditions. The polymeric hydrogels which have been used as 'bioinks' for tissue/organ 3D bioprinting including both natural and synthetic polymers and their combinations [18-20]. The hydrogels are usually formed by physical (reversible), chemical (reversible or irreversible) or biochemical (irreversible) crosslinking of homopolymer or copolymer solutions. Compared with synthetic polymers, the natural polymeric hydrogels can provide a benign and stable environment for cells/especially stem cells to grow, migrate, proliferate, and/or differentiate inside.

Over the last decade, natural polymers as the main components of 3D printable 'bioinks' have played a critical role in various 3D bioprinting technologies during the layered 3D construction processes. Cell behaviors within the natural polymeric hydrogels can be controlled through changing the physical/chemical/biochemical/physiological properties of the employed polymers. With these advanced sciences and technologies Professor X. Wang has overcome all the bottleneck problems, such as large scale-up tissue/organ engineering, living tissue/organ preservation, hierarchical vascular/neural network construction, complex bioartificial organ manufacturing, partly/fully controlled stem cell engagement (or differentiation), which have bewildered tissue engineers for more than three decades. In this review, we provide a comprehensive overview of 3D bioprinted natural polymers which have been used frequently in 3D bioprinting technologies. The intrinsic/extrinsic properties of the natural polymers for bioartificial organ 3D bioprinting have been outlined. Typical successful models have been highlighted.

\section{Properties of Natural Polymers}

Natural polymers, also referred to as bio-derived materials, occur in nature and can be extracted using physical or chemical methods. Examples of naturally occurring polymers include silk, wool, deoxyribonucleic acid (DNA), cellulose and proteins. These polymers have been widely applied in many industry areas, such as foods, textiles, papers, woods, adhesives, and pharmacies.

Some natural polymers, such as gelatin, alginate, fibrinogen, hyaluronic acid (or hyaluronan), are water-soluble, meaning that these polymers can dissolve in cell friendly inorganic solvents, such as cell culture medium and phosphate-buffered saline, to form solutions/hydrogels. The solution or hydrogel states of the natural polymers hold certain fluidity which makes them possible to be 3D printed layer-by-layer under the instructions of CAD models using the discrete-stacking RP, AM, or SFM principles [18-20]. Before, during, and after the 3D bioprinting process, the polymeric solutions/hydrogels offer cells and/or biomolecules (i.e., bioactive agents) a mild biomimic environment and facilitate cellular activities (i.e., cell-response bioactivities).

Theoretically, any natural polymers which have a sol-gel phase transition (i.e., gelation point) under certain conditions can be printed through an automatic layer-by-layer deposition method. In fact, 
very few natural polymers can be printed in layers at cell benign conditions (such as room temperature) without the help of physical/chemical/biochemcial crosslinking the incorporated polymer chains. This is due to that very few natural polymers can meet all the basic requirements for cell/tissue/organ 3D bioprinting [21-23].

During and after the 3D bioprinting process, natural polymers have played several essential roles in multiple cellular/biomolecular self/inter actions, homogeneous/heterogeneous histogenesis modulations/integrations/coordinations, and bioartifical organ generations/maturations. These essential roles include providing suitable accommodations for cellular/biomolecular activities (e.g., growth, migration, aggregation, proliferation, differentiation/mobilization, infiltration, coaction), enough space for extracellular matrix (ECM) patterns (e.g., formation, secretion, orientation), biophyscial/chemical cues for tissue/organ morphologies (e.g., formation, modeling, reshaping), and hierarchical vascular/neural/lymphatic network settings (e.g., construction, integration, figuration). The unexpected processing parameters, such as extreme temperatures, organic solvents and water deficiencies, which negatively influence the bioactivities of the encapsulated cells and/or biomolecules can be avoided effectively [24-26].

Over the last decade numerous natural polymers, such as gelatin, alginate, collagen, silk, hyaluronan, chitosan, fibrinogen, agar (or agarose), and decellularized extracellular matrix (dECM), have been printed either alone or together with other polymers as the main component of 'bioinks'. Each natural polymer has special physical characters (in response to various external stimuli, such as temperature, light, $\mathrm{pH}$, magnetism, and electricity), chemical properties, processing methods, cell-material interactions, and biomedical applications. Some other natural polymers, such as growth factors, resin, matrigel, poly (acrylic acid), polypeptide-DNA, anticoagulants (including heparin and coumarin), and polysaccharide (including dextran and starch), have been used occassionally in $3 \mathrm{D}$ bioprinting areas [27-30]. Small molecular materials and/or bioactive agents (or signals), such as ceramics, salts, sugars (including monose and fructose), and cryoprotectants (including dimethyl sulfoxide and glycerol), can be incorporated into the polymeric solutions or hydrogels through different approaches or protocols. These natural polymers have huge scientific research value and extravagant commercial profit in various biomedical fields. The currently available natural polymeric 'bioinks' as off-the-shelf products have been summarized in Table 1 [31-41].

Table 1. Commercially available natural polymeric 'bioinks'.

\begin{tabular}{|c|c|c|c|c|}
\hline 3D Bioprinting Technique & 'Bioink' Formulation & Crosslinking Method & Bioprinter & Ref. \\
\hline \multirow{2}{*}{$\begin{array}{l}\text { One/two nozzle } \\
\text { extrusion-based } \\
\text { 3D bioprinting }\end{array}$} & Alginate/chitosan hydrogel & $\mathrm{CaCl}_{2}$ solution & EFD $^{\circledR}$ Nordson printer & [32] \\
\hline & Nanocellulose-alginate & $\mathrm{CaCl}_{2}$ solution & 3D discovery printer & [33] \\
\hline \multirow{2}{*}{$\begin{array}{c}\text { Extrusion-based } \\
\text { scaffold-free bioprinting }\end{array}$} & Agarose hydrogel, Novogel & Sol-gel physical transition & Novogen Bioprinter & [34] \\
\hline & $\begin{array}{c}\text { Polyethylene glycol } \\
\text { (PEG)/gelatin-PEG/fibrinogen }\end{array}$ & $\begin{array}{l}\text { N-hydroxysuccinimide(NHS) } \\
\text { solutions for gelatin scaffold, } \\
\text { thrombin solutions for } \\
\text { fibrinogen-containing samples } \\
\text { post-printing }\end{array}$ & $\begin{array}{l}\text { EnvisionTEC } \\
\text { 3D-Bioplotter }\end{array}$ & [35] \\
\hline Inkjet-based 3D bioprinting & Fibrinogen solution & Thrombin solution & Custom-built printer & [38] \\
\hline $\begin{array}{c}\text { Fab }^{\circledR} \text { HomeTM } \\
\text { (one/two-syringe } \\
\text { extrusion-based 3D printing) }\end{array}$ & Gelatin/glucose-alginate hydrogel & $\mathrm{CaCl}_{2}$ solution after printing & $\mathrm{Fab}^{\circledR}$ Home Model1-3 & [39] \\
\hline 3D-Bioplot ter ${ }^{\mathrm{TM}}$ system & Alginate-PCL & $\mathrm{CaCl}_{2}$ aerosol $+\mathrm{CaCl}_{2}$ solution & Cartilage template & [40] \\
\hline Laser-based bioprinting & Alginate solution & $\mathrm{CaCl}_{2}$ solution & ExciStarexcimer laser & [41] \\
\hline
\end{tabular}


There are three prominent characteristics of these natural polymers for 3D bioprinting: good biocompatibility, poor mechanical strength and rapid biodegradability. In the following section, several representative natural polymers for organ 3D bioprinting have been reviewed in details from the aspects of 3D printability, biocompatibility, physical/chemical/biochemical crosslinkability, biodegradability and structural stability.

\section{Natural Polymers for Tissue/Organ 3D Bioprinting}

\subsection{Alginate}

Alginate, also called algin, is an anionic polysaccharide derived from brown algae. The term alginate is usually used for the salts of alginic acid, which is composed of $\beta$-D-mannuronic acid (M block) and $\alpha$-L-glucuronic acid (G block) (Figure 1), and can refer to all the derivatives of alginic acid and alginic acid itself [42]. Alginate can dissolve in water and be chemically crosslinked by divalent cations, such as calcium $\left(\mathrm{Ca}^{2+}\right)$, strontium $\left(\mathrm{Sr}^{2+}\right)$ and barium $\left(\mathrm{Ba}^{2+}\right)$ ions, which has been particularly attractive in wound healing, drug delivery and regenerative medicine [43-45]. The ratio between the $\mathrm{M}$ and $\mathrm{G}$ block is closely related to physiochemical properties of the alginate solution. A higher $\mathrm{G} / \mathrm{M}$ ratio provides rigidity to polymeric structure and mechanical properties, while lower $\mathrm{G} / \mathrm{M}$ ratio increases the flexibility [46,47].

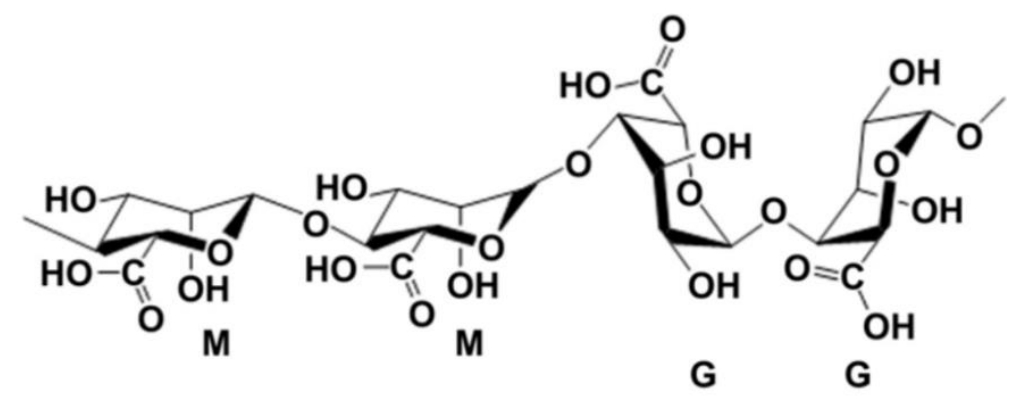

Figure 1. Structure units of alginate molecule [42].

Alginate and composite alginate hydrogels have been frequently used as cell-laden 'bioinks' in some 3D bioprinting technologies because their good biocompatibility (i.e., low toxicity, non-immunogenicity), rapid biodegradability, and chemical gelling capability (i.e., crosslinkable characteristic) [48]. Alginate related 3D bioprinting processes can be completed through different mechanisms, such as cell-laden hydrogel biopplotting in a plotting medium (crosslinker pool), coaxial nozzle-assisted crosslinking deposition with crosslinker spraying over the extruded cell-laden hydrogel, pre-crosslinked alginate hydrogel coextruded with cells [49,50]. Each of these 3D bioprinting technologies has pros and cons in tissue/organ 3D printing areas.

The first alginate application in 3D bioprinting is in 2003 by Professor X. Wang, when sodium alginate was printed with gelatin hydrogel as an additive [51]. Since the physical sol-gel transition of sodium alginate solution is below $0{ }^{\circ} \mathrm{C}$, which is much low than that of the gelatin solution $\left(28^{\circ} \mathrm{C}\right)$, it is difficult for the alginate hydrogel to be printed alone at room temperatures [52,53]. Physical blending and chemical crosslinking approaches have been employed in 3D bioprinting technologies from then on.

During the 3D bioprinting processes, the viscosity of the cell-laden alginate hydrogel depends largely on the polymer concentration, molecular weight, cell phenotype and density. Typically, when cells are embedded in an alginate hydrogel with high polymer concentration, their bioactivities are greatly restricted after chemical crosslinking. Meanwhile lower concentration of alginate hydrogel facilities higher cell viability and proliferation capability. Nevertheless, when the concentration of the alginate hydrogel is reduced, the mechanical strength of the 3D construct drops sharply even after chemical crosslinking. An optimized alginate concentration is necessary for a typical 3D bioprinting 
technology to ensure the favorable cell viability and printing resolution. In this respect, Park et al. summarized the suitable concentration and molecular weight of alginate hydrogel for soft tissue bioprinting in consideration of mechanical property (i.e., module), printability and cell viability. It was reported that the alginate hydrogel composed of $3 \mathrm{wt} \%$ alginate with a mixture of low and high molecular weights in a 1:2 ratio displayed a good printability, favorable cell viability and proliferation capability after printing for seven days [54]. Additionally, the blends of alginate hydrogel with other polymers, such as gelatin, collagen and nano-fibrillated cellulose can effectively enhance the cellular activities as well as the printing resolution from $1000 \mu \mathrm{m}$ to $400-600 \mu \mathrm{m}$ with a $300 \mu \mathrm{m}$ diameter nozzle [55]. Other processing parameters including nozzle size, surrounding temperature, scanning speed and dispensing pressure can also influence the printing resolution.

There are two common phenomena in alginate 3D bioprinting. The first one is that it is hard for the pure alginate solution with a low polymer concentration to be printed layer-by-layer into a high scale-up construct due to its low phase changing temperature (i.e., sol-gel transition point) and shear thinning characteristic [42]. Another common phenomenon is that the slow biodegradation velocity of alginate molecules can be tuned by oxidation procedures [56]. The oxidized alginate molecules with an appropriate degradation rate may have more potential usage in organ 3D printing. In this respect, Jia et al. focused on oxidizing alginate molecules to control the alginate printability and degradability. Accurate lattice-structures (with higher accuracies) could be obtained through optimizing the oxidized alginate solutions before printing. Human adipose-derived stem cells (hADSCs) could be loaded in the oxidized alginate solutions as well. The oxidation percentage (ox.) and concentration (conc.) of the alginate had been summarized in their research. The results indicated that $0 \%$ ox. $-8 \%$ conc. alginate induced a round cell morphology that might apply to chondrogenesis, while $5 \%$ ox.- $15 \%$ conc. alginate associated with an increased spreading cell phenotype that might improve osteogenesis. The $5 \%$ ox. $-15 \%$ conc. alginate was recommended as the most appropriate formulation of their 'bioinks' for 3D bioprinting. The available literature on alginate as 'bioinks' for 3D bioprinting technologies is summarized in Table 2 according to the chronological sequence [57-88]. 
Table 2. Alginate containing 'bioinks' for different 3D bioprinting applications.

\begin{tabular}{|c|c|c|c|c|}
\hline 3D Bioprinting Technique & ‘Bioink' Formulation & Crosslinking Method & Application & Ref. \\
\hline \multirow{3}{*}{$\begin{array}{l}\text { One nozzle extrusion-based } \\
\text { 3D bioprinting }\end{array}$} & $\begin{array}{l}\text { Hepatocytes and chondrocytes in } \\
\text { gelatin/alginate hydrogel }\end{array}$ & $\begin{array}{l}10 \% \mathrm{CaCl}_{2} \text { solution for } 2 \mathrm{~min} \\
\text { after printing }\end{array}$ & $\begin{array}{l}\text { Bioartificial liver or } \\
\text { cartilage manufacturing }\end{array}$ & [51] \\
\hline & $\begin{array}{l}\text { Adipose-derived stem cells (ADSCs) in } \\
\text { gelatin/alginate hydrogel }\end{array}$ & $5 \% \mathrm{CaCl}_{2}$ solution after printing & Vascular networks & [52] \\
\hline & ADSCs in alginate capsules and gelatin/alginate hydrogel & $5 \% \mathrm{CaCl}_{2}$ solution after printing & Vascular networks & [53-56] \\
\hline \multirow{3}{*}{$\begin{array}{l}\text { One nozzle extrusion-based 3D } \\
\text { low-temperature bioprinting }\end{array}$} & $\begin{array}{c}\text { Adipose-derived stem cells (ADSCs) in } \\
\text { gelatin/alginate/fibrinogen/dimethylsulfoxide } \\
\text { (DMSO) hydrogel }\end{array}$ & $\begin{array}{l}\text { Double crosslinking with } \mathrm{CaCl}_{2} \\
\text { and thrombin after printing }\end{array}$ & No specific & [57] \\
\hline & $\begin{array}{l}\text { Adipose-derived stem cells (ADSCs) in } \\
\text { gelatin/alginate/DMSO and/or dextrain- } 40 \text { hydrogel }\end{array}$ & $5 \% \mathrm{CaCl}_{2}$ solution after printing & No specific & [58] \\
\hline & $\begin{array}{l}\text { Adipose-derived stem cells (ADSCs) in } \\
\text { gelatin/alginate/glycerol and/or dextrain- } 40 \text { hydrogel }\end{array}$ & $5 \% \mathrm{CaCl}_{2}$ solution after printing & No specific & [59] \\
\hline \multirow{3}{*}{$\begin{array}{l}\text { Two nozzle extrusion-based } \\
\text { 3D bioprinting }\end{array}$} & $\begin{array}{l}\text { Adipose-derived stem cells (ADSCs) in } \\
\text { gelatin/alginate/fibrinogen hydrogel \& hepatocytes in } \\
\text { gelatin/alginate/chitosan hydrogel }\end{array}$ & $\begin{array}{l}\text { Double crosslinking with } \mathrm{CaCl}_{2} \\
\text { and thrombin after printing }\end{array}$ & $\begin{array}{l}\text { Vascularized liver tissue } \\
\text { manufacturing }\end{array}$ & [60] \\
\hline & $\begin{array}{l}\text { Adipose-derived stem cells (ADSCs) in } \\
\text { gelatin/alginate/fibrinogen hydrogel }\end{array}$ & $\begin{array}{l}\text { Double crosslinking with } \mathrm{CaCl}_{2} \\
\text { and thrombin after printing }\end{array}$ & $\begin{array}{l}\text { Vascularized adiose tissue } \\
\text { manufacturing }\end{array}$ & [61] \\
\hline & $\begin{array}{l}\text { Adipose-derived stem cells (ADSCs) in } \\
\text { gelatin/alginate/fibrinogen hydrogel }\end{array}$ & $\begin{array}{l}\text { Double crosslinking with } \mathrm{CaCl}_{2} \\
\text { and thrombin after printing }\end{array}$ & $\begin{array}{l}\text { Bioartificial pancreas } \\
\text { manufacturing }\end{array}$ & [62] \\
\hline $\begin{array}{l}\text { Mutihead deposition system } \\
\quad \text { (extrusion-based) }\end{array}$ & $\begin{array}{l}\text { Osteoblasts \& chondrocytes in polycaprolactone } \\
\text { (PCL)/alginate solution }\end{array}$ & $\mathrm{CaCl}_{2}$ solution after printing & Osteochondral tissue & [63] \\
\hline $\begin{array}{l}\text { One nozzle extrusion-based } \\
\text { 3D bioprinting }\end{array}$ & Cartilage progenitor cell (CPCs) in alginate solution & $\mathrm{CaCl}_{2}$ solution after printing & Vessel-like structure & [64] \\
\hline $\begin{array}{l}\text { Fab@HomeTM (one-syringe } \\
\text { extrusion-based 3D printing) }\end{array}$ & $\begin{array}{l}\text { Aortic valve leaflet interstitial cells (VICs), smooth muscle } \\
\text { cells (SMCs) or chondrocytes in gelatin/alginate solution }\end{array}$ & $\begin{array}{l}300 \mathrm{mM} \mathrm{CaCl}_{2} \text { crosslinking for } \\
10 \text { min after printing }\end{array}$ & $\begin{array}{l}\text { Myocardial tissue, muscle tissue } \\
\text { and cartilage engineering }\end{array}$ & [65] \\
\hline $\begin{array}{l}\text { One-nozzle extrusion-based } \\
\text { 3D bioprinting }\end{array}$ & Myoblasts in gelatin/alginate hydrogel & $\mathrm{CaCl}_{2}$ solution after printing & Muscle engineering & [66] \\
\hline $\begin{array}{l}\text { Two-nozzle low-temperature } \\
\text { extrusion-based 3D bioprinting }\end{array}$ & PU-ADSCs in gelatin/alginate/fibrinogen hydrogel & $\begin{array}{l}\text { Double crosslinking with } \mathrm{CaCl}_{2} \\
\text { and thrombin }\end{array}$ & Complex organ manufacturing & {$[67,68]$} \\
\hline
\end{tabular}


Table 2. Cont

\begin{tabular}{|c|c|c|c|c|}
\hline 3D Bioprinting Technique & ‘Bioink' Formulation & Crosslinking Method & Application & Ref. \\
\hline $\begin{array}{l}\text { Combined four-nozzle } \\
\text { 3D bioprinting }\end{array}$ & $\begin{array}{l}\text { Poly(lactic acid-co-glycolic acid) (PLGA)-ADSCs in } \\
\text { gelatin/alginate/fibrinogen hydrogel-hepatocytes in } \\
\text { gelatin/chitosan hydrogel-Schwann cells in } \\
\text { gelatin/hyaluronate hydrogel }\end{array}$ & $\begin{array}{l}\text { Double crosslinking with } \mathrm{CaCl}_{2} \\
\text { and thrombin }\end{array}$ & $\begin{array}{l}\text { Vascularized liver } \\
\text { manufacturing }\end{array}$ & [69] \\
\hline $\begin{array}{l}\text { One nozzle extrusion-based } \\
\text { 3D bioprinting }\end{array}$ & Gelatin/alginate hydrogel & $\begin{array}{l}\mathrm{CaCl}_{2} \text { crosslinking } \\
\text { after printing }\end{array}$ & No specific & [70] \\
\hline $\begin{array}{l}\text { One nozzle extrusion-based } \\
\text { 3D bioprinting }\end{array}$ & $\begin{array}{c}\text { Human adipose stem cells (hASCs) in oxidized } \\
\text { alginate solution }\end{array}$ & $\begin{array}{l}\mathrm{CaCl}_{2} \text { crosslinking } \\
\text { after printing }\end{array}$ & No specific & {$[71]$} \\
\hline Micro imprinting & $\begin{array}{l}\text { Mesenchymal stem cells (MSCs) in } \\
\text { gelatin/alginate/hydroxyapatite (HA) mixture }\end{array}$ & $\begin{array}{l}2 \% w / v \mathrm{CaCl}_{2} \text { crosslinking for } \\
10 \text { min after printing }\end{array}$ & Cartilage tissue & [72] \\
\hline $\begin{array}{l}\text { One nozzle extrusion-based } \\
\text { 3D bioprinting }\end{array}$ & Preosteoblasts and hASCs in alginate solution & $1.2 \mathrm{wt} \%$ of $\mathrm{CaCl}_{2}$ flow & Hepatogenic differentiation & [73] \\
\hline $\begin{array}{l}\text { Mutihead deposition system } \\
\text { (extrusion-based) }\end{array}$ & Chondrocytes in PCL/alginate solution & $\begin{array}{l}100 \mathrm{mM} \mathrm{CaCl}_{2} \text { and } 145 \mathrm{mM} \\
\mathrm{NaCl} \text { solution for } 10 \mathrm{~min}\end{array}$ & Cartilage & [74] \\
\hline $\begin{array}{l}\text { One nozzle extrusion-based } \\
\text { 3D bioprinting }\end{array}$ & $\begin{array}{l}\text { Human umbilical vein endothelial cells in methacrylated } \\
\text { gelatin (GelMA)/alginate hydrogel }\end{array}$ & $\begin{array}{l}\text { Photopolymerization and } \mathrm{CaCl}_{2} \\
\text { solution }\end{array}$ & Heart tissue & [75] \\
\hline $\begin{array}{l}\text { Two-nozzle extrusion-based 3D } \\
\text { printing }\end{array}$ & $\begin{array}{c}\text { Gelatin/alginate/fibrinogen/HepG } 2 \\
\text { gelatin/alginate/fibrinogen/hepatocyte or } \\
\text { gelatin/alginate/fibrinogen/hepatocyte/ADSC }\end{array}$ & $\begin{array}{l}\text { Double crosslinking with } \mathrm{CaCl}_{2} \\
\text { and thrombin solutions }\end{array}$ & $\begin{array}{l}\text { Liver tumor model } \\
\text { establishment and anti-cancer } \\
\text { drug screening }\end{array}$ & [76-78] \\
\hline 3D-Bioplot ter ${ }^{\mathrm{TM}}$ system & Alginate-PCL & $\begin{array}{l}170 \mathrm{mM} \mathrm{CaCl}_{2} \text { aerosol }+100 \\
\mathrm{mM} \mathrm{CaCl}_{2} \text { solution }\end{array}$ & Cartilage template & [79] \\
\hline Multi-head bioprinting & $\begin{array}{l}\text { RGD- } \gamma \text { alginate/poly(-ethylene glycol)-tetra-acrylate } \\
\text { (PEGTA)/GelMA/PCL }\end{array}$ & UV light for $30 \mathrm{~min}$ & Cartilage engineering & [80] \\
\hline $\begin{array}{l}\text { A multilayered coaxial } \\
\text { extrusion system }\end{array}$ & $\begin{array}{c}\text { A specially designed cell-responsive bioink consisting of } \\
\text { GelMA, alginate, and 4-arm poly(-ethylene } \\
\text { glycol)-tetra-acrylate (PEGTA) }\end{array}$ & $\begin{array}{l}\text { First ionically crosslinked by } \\
\text { calcium ions }\left(\mathrm{Ca}^{2+} \text { ion }\right) \\
\text { followed by covalent } \\
\text { photocrosslinking of GelMA } \\
\text { and PEGTA }\end{array}$ & Perfusable vasculature & [81] \\
\hline
\end{tabular}


Table 2. Cont.

\begin{tabular}{|c|c|c|c|c|}
\hline 3D Bioprinting Technique & ‘Bioink' Formulation & Crosslinking Method & Application & Ref. \\
\hline \multirow{4}{*}{$\begin{array}{l}\text { One nozzle extrusion-based } \\
\text { 3D bioprinting }\end{array}$} & Fibroblasts in gelatin/alginate hydrogel & $\mathrm{CaCl}_{2}$ solution & Skin wound healing & [82] \\
\hline & Alginate/polyvinyl alcohol (PVA) & $\mathrm{CaCl}_{2}$ solution & $\begin{array}{l}\text { As-prepared bone tissue } \\
\text { engineering scaffolds }\end{array}$ & [83] \\
\hline & $\begin{array}{l}\text { Mouse calvaria 3T3-E1 (MC3T3) cells in } \\
\text { alginate/PVA/hydroxyapatite (HA) hydrogel }\end{array}$ & $\mathrm{CaCl}_{2}$ solution & Bone tissue engineering & [84] \\
\hline & Alginate/PVAl/HA/collagen hydrogel & $\mathrm{CaCl}_{2}$ solution & Bone tissue engineering & [85] \\
\hline $\begin{array}{c}\text { One nozzle } \\
\text { extrusion-based bioploting }\end{array}$ & Human dental pulp cells (HDPCs) in gelatin/alginate hydrogel & $\mathrm{CaCl}_{2}$ solution & Tooth regeneration & [86] \\
\hline $\begin{array}{c}\text { Extrusion-based } \\
\text { microvalvebioprinting }\end{array}$ & Alginate sulfate/nanocellulose/chondrocytes & $\begin{array}{l}100 \mathrm{mM} \mathrm{CaCl}_{2} \text { for } 12 \mathrm{~min} \\
\text { after printing }\end{array}$ & Cartilage engineering & [87] \\
\hline $\begin{array}{l}\text { One nozzle extrusion-based } \\
\text { 3D bioprinting }\end{array}$ & $\begin{array}{l}\text { Human-derived induced pluripotent stem cells (iPSCs) in } \\
\text { nanofibrillated cellulose (NFC)/alginate solution }\end{array}$ & $\begin{array}{l}100 \mathrm{mM} \mathrm{CaCl}_{2} \text { for } 5 \mathrm{~min} \\
\text { prior printing }\end{array}$ & Cartilage engineering & [88] \\
\hline
\end{tabular}




\subsection{Gelatin}

Gelatin is a partial hydrolyzed protein by breaking the triple helix of collagen into single-strain molecules. It is a thermal-response linear polymer. Gelatin and its derivatives have been widely applied in 3D bioprinting due to their excellent biocompatibility, high water-adsorbing capacity, rapid biodegradability, non-immunogenicity and unique 3D printability (Figure 2) [53-67,89]. Gelatin solution has a unique sol-gel transition at $28{ }^{\circ} \mathrm{C}$, which is corresponding to the melt point of gelatin hydrogel.

Before printing, the bulk gelatin-based polymers need to dissolve in an inorganic solvent, such as phosphate-buffered saline or cell culture medium, to form fluidic solutions with a suitable viscosity. Any types of cells and/or bioactive agents (such as growth factors, hormones, anticoagulants and cryoprotectants) can be incorporated into the gelatin solutions [90]. After the cells and/or bioactive agents are mixed with the gelatin-based solutions, the cells and/or bioactive agents are suspended in the solutions. When the solutions are cooled below $28^{\circ} \mathrm{C}$, the fluidic solutions become sticky hydrogels accompanying with a sol-gel transition phenomenon. Physical crosslinking (i.e., gelling or gelation) among the gelatin molecules happens during the sol-gel transition processes. The incorporated cells and/or bioactive agents are reversibly embedded (or encapsulated) by the polymeric chains. Other natural polymers, such as alginate, chitosan, fibrinogen, hyaluronan, collagen, agar and matrigel, can be incorporated into the gelatin solutions as additives, leading to the gelatin solutions/hydrogels being printed alone or together with the other polymeric additives as the cell/bioactive agent-laden 'bioinks' [91]. Chemical crosslinking of the polymeric molecules is an effective approach to enhance the mechanical properties and structural stability of the 3D printed constructs. Ten years later, these techniques have been world widely adapted, duplicated or copied by many other groups, such as the A. Atala's at Wake Forest School of Medicine in North Carolina [92], and the J.A. Lewis's in Harvard University [93].

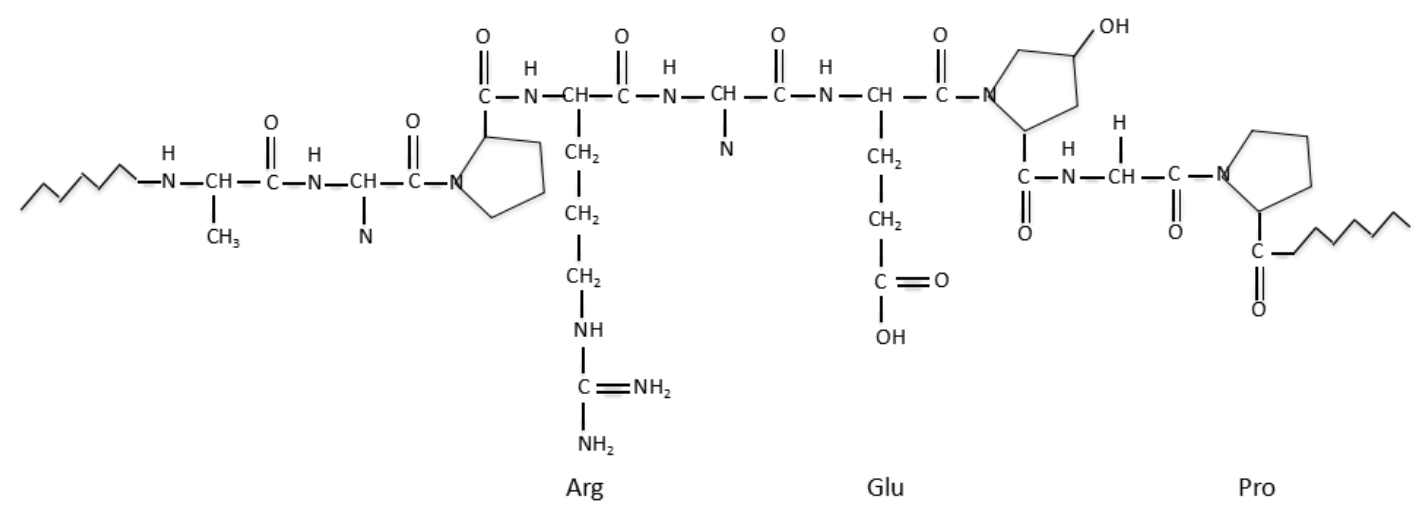

Figure 2. Molecular structure of gelatin.

Thus, the special thermal response character of the gelatin based solutions/hydrodgels allow cells and/or bioactive agents to be injected or extruded through the nozzles/needles of 3D bioprinters and subsequently piled up in layers at a relatively benign environmental temperature between $1-28^{\circ} \mathrm{C}$. During and after the 3D printing processes, the gelatin based solutions/hydrogels act both as the backbones (such as the ECMs) to support the structural integrity of the 3D constructs and the accommodations for cells and/or bioactive agents within the predefined 3D constructs.

Especially, in extrusion-based 3D bioprinting technologies, the printing processes can be tuned to be no harm (or adverse effect) to the incorporated cells and/or bioactive agents with respect to the applied parameters, such as shear forces, squeeze rates and nozzle sizes. Cell viability, especially stem cell proliferation and differentiation capabilities, can be preserved. Extremely high cell viabilities (i.e., $100 \%$ percentage) can be achieved by optimizing the printing parameters, such as the nozzle diameter, acting force, printing speed and surrounding temperature [11-13,57-62]. Additionally, 
the presence of arginine-glycine-aspartic acid (or Arg-Gly-Asp, RGD) peptide domains in the gelatin molecules may have favorable effects on cell activities, such as migration and differentiation [94].

Obviously, there are two distinguished disadvantages of the gelatin-based hydrogels in organ $3 \mathrm{D}$ printing areas: one is the low mechanical strength and the other is the structural instability under physiological conditions (such as $37^{\circ} \mathrm{C}$ ). It is observed that when the printed cell-laden 3D constructs are put into culture medium at about $37^{\circ} \mathrm{C}$, the physical crosslinked gel states (or structures) break down quickly. This is because that above the melt point of $28^{\circ} \mathrm{C}$, the physical crosslinking bonds in the gelatin molecules disorganize, leading to the collapses of the structural integrity of the 3D constructs. In another word, the gelled gelatin-based constructs disperse immediately in the culture medium due to the reversible physical crosslinking bonds. The 3D printed gelatin-based constructs need to be further strengthened to yield a stable structure.

Consequently, various physical blending and chemical crosslinking techniques have been applied to improve the mechanical property and structural stability of the 3D printed constructs. For example, gelatin molecules have been chemically modified with methacrylamide groups to yield a natural/synthetic hybrid hydrogel (i.e., gelatin/methacrylate, GelMA). The hybrid GelMA hydrogel can be photopolymerized in the presence of a water-soluble photoinitiator and ultraviolet (UV) [95]. It is reported that the increase of the gelatin or GelMA proportion (or concentration) can significantly elevate the viscosity and printability of the composite GelMA hydrogel. The UV crosslinking of GelMA can dramatically enhance the mechanical properties and shape fidelity of the 3D printed constructs. The shape fidelity can be subsequently improved from $1100-1300 \mu \mathrm{m}$ to $350-450 \mu \mathrm{m}$ using a $200 \mu \mathrm{m}$ diameter nozzle. Cell survival capability in the GelMA hydrogel can reach $83 \%$ with a cell density of $1.5 \times 10^{6}$ cells $/ \mathrm{mL}, 10 \%$ GelMA hydrogel and $60 \mathrm{~s}$ UV exposure. HepG2 in the GelMA constructs can retain a high cell viability for at least eight days, possibly due to the protective effect of the composite GelMA hydrogels, in which the shear stress applied on the encapsulated cells resulting from the friction of the hybrid cell-laden hydrogels with the nozzle walls.

Another example is that the gelatin-based hydrogels can be chemically crosslinked by some small bioactive agents (or chemicals), such as glutaraldehyde and $\mathrm{CaCl}_{2}$ [96]. The rapid biodegradation property of the gelatin-based hydrogels, such as the gelatin, gelatin/alginate, gelatin/chitosan, and gelatin/fibrinogen, has been greatly enhanced through the chemical crosslinked polymer chains. Typical chemical crosslinked gelatin based hydrogels contain the glutaraldehyde crosslinked gelatin molecules, $\mathrm{CaCl}_{2}$ crosslinked alginate molecules, tripolyphosphate (TPP) crosslinked chitosan molecules, and thrombin polymerized fibrinogen molecules. Much more stable 3D constructs can be obtained through double/triple crosslinking the composite (or hybird) gelatin-based hydrogels. For instance, gelatin/algiante/fibrinogen hydrogel is a natura/natural/natural hybrid hydrogel, it can be effectively stabilized through double crosslinking the polymer molecules in the hybrid hydrogel using both $\mathrm{CaCl}_{2}$ and thrombin solutions (i.e., using $\mathrm{CaCl}_{2}$ to crosslink the algiante molecules and thrombin to polymerize the fibrinogen molecules in the gelatin/alginate/fibrinogen hydrogels). Though progressive loss of the uncrosslinked gelatin molecules in the long-term in vitro cultured gelatin/alginate/fibrin constructs has been detected, the living 3D constructs can be maintained properly over four weeks until the new tissue/organ generation [11-13]. The representative literature on the gelatin-based hydrogels as 'bioinks' in tissue/organ 3D bioprinting is summarized in Table 3 except those appeared in Table 2 [97-106]. 
Table 3. Gelatin containing 'bioinks' for different 3D bioprinting applications.

\begin{tabular}{|c|c|c|c|c|}
\hline 3D Bioprinting Technique & 'Bioink' Formulation & Crosslinking Method & Application & Ref. \\
\hline \multirow{4}{*}{$\begin{array}{l}\text { One nozzle extrusion-based 3D } \\
\text { low-temperature bioprinting }\end{array}$} & Hepatocytes in gelatin/chitosan hydrogel & $3 \%$ sodium tripolyphosphate (TPP) & Hepatic tissue manufacturing & [97] \\
\hline & Hepatocytes in gelatin hydrogel & $2.5 \%$ glutaraldehyde & Hepatic tissue manufacturing & [98] \\
\hline & Hepatocytes in gelatin/fibrinogen hydrogel & Thrombin induced polymerization & Hepatic tissue manufacturing & [99] \\
\hline & Gelatin/hyluronan & $2 \%$ glutaraldehyde & Brain tissue repair & {$[100$} \\
\hline \multirow{2}{*}{$\begin{array}{l}\text { Two-nozzle low-temperature } \\
\text { extrusion-based 3D printing }\end{array}$} & $\begin{array}{c}\text { Polyurethane (PU)-gelatin } / 5 \% \text { or } 10 \% \\
\text { lysine hydrogel }\end{array}$ & $0.25 \%$ glutaraldehyde & Liver manufacturing & {$[101$} \\
\hline & $\begin{array}{c}\text { PU-adipose-derived stem cell } \\
\text { (ADSC)/gelatin/alginate/fibrinogen/glycerol or } \\
\text { dimethyl sulfoxide (DMSO) hydrogel }\end{array}$ & $\begin{array}{l}\text { Double crosslinking with } \mathrm{CaCl}_{2} \\
\text { and thrombin solutions }\end{array}$ & Bioartificial liver manufacturing & {$[102$} \\
\hline $\begin{array}{l}\text { One-syringe extrusion-based } \\
\text { 3D printing }\end{array}$ & Nanosilicate/GelMA & $\begin{array}{l}\text { UV light (320-500 nm) for } 60 \mathrm{~s} \text { at an } \\
\text { intensity of } 6.9 \mathrm{~mW} / \mathrm{cm}^{2}\end{array}$ & $\begin{array}{c}\text { Electrical conductive agent for } \\
\text { bone tissue engineering }\end{array}$ & {$[103$} \\
\hline EnvisionTEC 3D-Bioplotter ${ }^{\circledR}$ & $\begin{array}{c}\text { Polyethylene glycol } \\
\text { (PEG)/gelatin-PEG/fibrinogen }\end{array}$ & $\begin{array}{c}\text { Gelatin scaffolds were cross-linked } \\
\text { with } 15 \mathrm{mM} \text { EDC and } 6 \mathrm{mM} \mathrm{NHS} \text {, } \\
\text { fibrinogen-containing samples were } \\
\text { treated post-printing with } 10 \mathrm{U} / \mathrm{mL} \\
\text { thrombin in } 40 \mathrm{mM} \mathrm{CaCl} \text { for } \\
\quad 30 \mathrm{~min}\end{array}$ & Grid structures for cell seeding & {$[104$} \\
\hline $\begin{array}{l}\text { Dual-syringe Fab@Home } \\
\text { printing device }\end{array}$ & $\begin{array}{c}\text { Gelatin ethanolamide methacrylate } \\
\text { (GE-MA)-methacrylated hyaluronic acid (HA-MA) } \\
\text { (GE-MA-HA-MA)/HepG2 C3A, NIH 3T3, or } \\
\text { Int-407 cell }\end{array}$ & $\begin{array}{l}\text { Ultraviolet (UV) light (365nm, } \\
180 \mathrm{~mW} / \mathrm{cm}^{2} \text { ) photocrosslinking }\end{array}$ & $\begin{array}{l}\text { Tubular hydrogel structures for } \\
\text { cell attachment }\end{array}$ & {$[105$} \\
\hline $\begin{array}{l}\text { Multiple cartridge } \\
\text { extrusion-based 3D printer }\end{array}$ & $\begin{array}{c}\text { Polycaprolactone } \\
\text { (PCL)-gelatin/fibrinogen/hyaluronic } \\
\text { acid/glycerol }\end{array}$ & $\begin{array}{l}\text { Thrombin induced } \\
\text { fibrinogen polymerization }\end{array}$ & $\begin{array}{l}\text { Bone, cartilage and skeletal } \\
\text { muscle tissues }\end{array}$ & [91] \\
\hline $\begin{array}{l}\text { One nozzle extrusion-based } \\
\text { 3D bioprinting }\end{array}$ & $\begin{array}{l}\text { Human mesenchymal stem cells (MSCs) in } \\
\text { gelatin/alginate/hydroxyapatite (HA) mixture }\end{array}$ & $\begin{array}{l}2 \% w / v \mathrm{CaCl}_{2} \text { crosslinking for } \\
10 \text { min after printing }\end{array}$ & Bone tissue & [40] \\
\hline Inkject-based 3D bioprinting & FC3T3 in fibrin-gelatin hydrogel & Thrombin solution & Skin tissue engineering & {$[106$} \\
\hline
\end{tabular}




\subsection{Hyaluronic Acid}

Hyaluronic acid (HA) or hyaluronan is a polysaccharide existing in living organisms composed of D-glucuronic acid and N-acetyl-D-glucosamine (Figure 3) [107]. As a component of ECM, HA has excellent biocompatibility and biodegradability, which has played an essential role in cell proliferation, angiogenesis and cell-receptor interactions. HA can be rapidly degraded (i.e., glycolytically degraded in a glycolytic pathway) by hyaluronidase, $\beta$-glucuronidase and $\beta$-N-acetyl-glucosaminidase into low molecule weight hyaluronic acid and oligosaccharides $[108,109]$. It is a lubricating hydrophilic polymer that can form highly viscous hydrogels at low concentrations, and can be applied as an additive to alter the viscosity of the above mentioned gelatin based 'bioinks'.

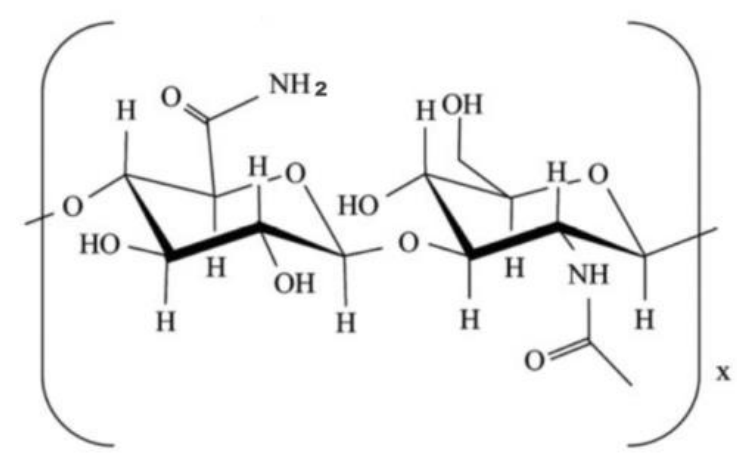

Figure 3. Structure unit of hyaluronic acid (HA).

Like most of the natural polymers, HA has poor mechanical properties which result in low shape fidelity during 3D bioprinting. Numerous modifications have been carried out to improve the mechanical properties and shape fidelity of the HA based 3D printing processes. These modifications include physical or chemical crosslinking of HA with other polymers. For example, hyaluronic acid methacrylate (HAMA) is a natural/synthetic hybrid polymer generated by photochemically crosslinking HA and methacrylate using UA-light source [110]. Emphasis should be given that although HAMA has altered the poor physical properties of the HA, the bioinert characters of the HAMA, including non-biodegradability of polymethacrylate (i.e., PMA), high hardness (or stiffness) and low shape fidelity, have greatly limited its application in organ 3D bioprinting areas [111].

Another example is the gelatin or GelMA blended HA (e.g., HAMA-GelMA). The printing parameters of the hybrid HAMA-GelMA (i.e., concentration or composition ratio) directly affect the mechanical properties of the printed 3D constructs, the degradation rate of the natural components in the 3D constructs, as well as the cell spreading, adhesion and proliferation features in the 3D constructs. In this respect, Camci-Unal et al. reported that the addition of $1 \% v / w$ HAMA into the GelMA hydrogel could decrease the mass swelling ratio and degradation rate, but increased the compressive moduli of the 3D constructs. No cell spreading was found within the 3D printed HAMA construct. Cell spreading could only be observed in the samples with 3\% GelMA and 1\% HAMA, possibly due to the existence of the cell adhesive motifs in the gelatin molecules [112].

Until the present, the hybrid HAMA-GelMA 'bioinks' with proper proportion of HAMA and GelMA have been applied in some tissue engineering applications, including neural, cardiovascular, cartilage and bone tissues. One example is that Duan et al. have improved the spreading and adhesive capabilities of the human aortic valvular interstitial cells, and the phenotype maintaining ability of the fibroblasts in the 3D printed trileaflet valve conduits through increasing the GelMA concertration in the hybrid HAMA-GelMA hydrogels (with decreased stiffness) [113]. Similar results have been found by Skardal and coworkers through changing the ratio of HAMA and GelMA, Skardal et al. reported that a high ratio of HAMA/GelMA would result in a stiffer construct, but poor cell adhesive ability, while low ratios lead to poor mechanical strengths but better cell adhesions. The $80 / 20$ ratio of HAMA/GelMA was an optimal choice with all aspects considered [101]. 


\subsection{Collagen}

Natural collagen has been widely used as a scaffold material for tissue engineering over the last several decades (Figure 4). It can significantly improve the adhesion, proliferation and differentiation capabilities of osteoblasts, chondroblasts, and mesenchymal stem cells on the porous scaffolds [114]. Especially, the pore size of 50-150 $\mu \mathrm{m}$ of the collagen scaffold facilitates cell seeding on the surface of the pores. It is supposed that the collagen molecule, which has the same RGD peptide domains with gelatin, can be recognized by integrin receptors on the cell membrane and promote cell adhesion and proliferation. Nonetheless, the properties of acid-soluble collagen solution can be easily affected by the potential of hydrogel $(\mathrm{pH})$ and temperature, which make it difficult for the collagen solution to be $3 \mathrm{D}$ printed at ambient conditions. The reason is that collagen molecules tend to assemble to form hydrogel and can be rapidly degraded by collagenases and metalloproteinases into amino acids when the solution is neutralized at $37^{\circ} \mathrm{C}$.

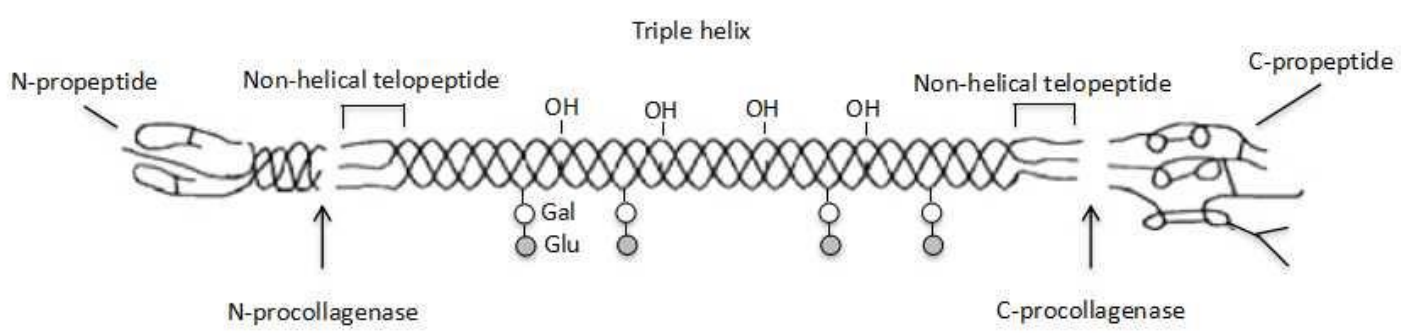

Figure 4. Schematic diagram of collagen molecule.

Especially, collagen type I and II have been frequently employed for cartilage and bone repair scaffold 3D printing. There are three obvious advantages for the 3D printed scaffolds to be used for tissue repair. Firstly, most of the 3D printed scaffolds have scale-up go-through channels, which are different from the traditional tissue engineering porous scaffolds, and helpful for nutrient, oxygen, and metabolite transportation. Secondly, the structural morphology and material composite of 3D printed scaffolds can be gradient, which are benefit for multiple functionality realization. Thirdly, living cells can be directly incorporated into the biocompatible materials for hard/soft tissue/organ engineering. For example, the articular cartilage has a zonal ECM distribution with gradient cell density from articular surface to calcified cartilage. One of the main defects of conventional tissue engineered articular cartilage is the difficult to mimic zonal mechanical and biological properties of natural cartilage, while bioprinting technologies have the capability to fabricate well-designed constructs with accuracy cell distribution [115]. A study by Ren et al. focused on the engineered zonal cartilage by bioprinting collagen type II hydrogel constructs with a gradient chondrocyte density. In this study, collagen type II had the ability to maintain chondrocyte phenotype and played an essential role to promote chondrogenic differentiation. The 3D printed zonal cartilage had a gradient ECM distribution, which was positively correlated to chondrocyte density. Both the both the cell density and cell distribution pattern in the bioprinting process had been modulated in different zonal areas for better biological effects [116].

Until now, the low viscosity and fast degrading rate of the pure collagen hydrogels have seriously limited their applications as 'bioinks' in tissue/organ 3D bioprinting. Blending with other polymers, such as alginate, fibrin, agarose, and hyaluronic acid, has become the most common strategies to alter the viscosity, degradation rate, and printability of the natural collagen [114]. However, the blending of collagen with alginate or agarose has greatly comprised the cell viability. This is because that the ultimate biocompatibility of the blend is determined by the worst of component of the composite, such as alginate in the collagen/alginate hydrogel and agarose in the collagen/agarose hydrogel. On the contrary, a hybrid of chondrocyte-encapsulated hyaluronic acid and osteoblast-encapsulated collagen type I hydrogel was reported for osteochondral bioprinting with good results [117]. Recently, a 3D bioprinted collagen/heparin sulfate scaffold was reported to promote neurological function recovery by providing continuous guidance channels for axons and enough mechanical strength for the injured 
spinal cord. The heparin modification has resulted in enhanced compress modulus and binding affinity of the new secreted ECM proteins [118].

In our group, collagen I has been printed with polyurethane simultaneously using our home-made double-nozzle low-temperature 3D bioprinter for a double layer nerve repair conduit manufacture [119-121]. Swann cell compatibility in the double layer nerve repair conduit has been significantly improved. Meanwhile nerve repair speed inside double layer nerve repair conduit has been the has been extremely accelerated.

\subsection{Fibrin}

Fibrin is a blood-derived fibrous (i.e., non-globular) protein formed by polymerizing fibrinogen in the presence of the protease thrombin (Figure 5) [121]. Over the last several decades, fibrin has been widely used in many biomedical fields, such as pharmacy, wound healing, and tissue repair. Compared with plant-derived natural polymers, such as alginate and agarose, fibrin has excellent biocompatibilities in biomedical fields. In the context of cell viability, fibrin hydrogel, has super cytocompatibility for cell encapsulation, delivery and culture [122-124]. With respect to the degradation velocity, fibrin can degrade rapidly due to the presence of proteolytic enzymes [125].

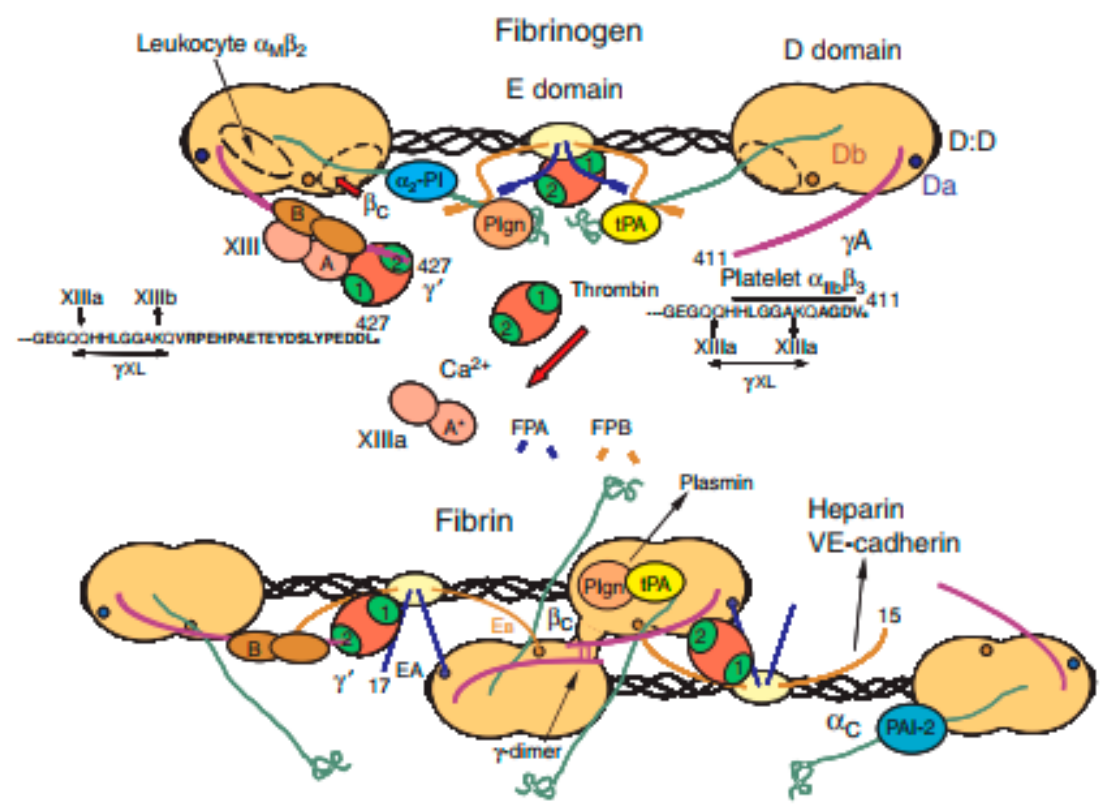

Figure 5. Schematic structures of fibrinogen and fibrin [121].

Despite the superior biological/biochemical/biomedical properties, the low viscosity, rapid gelation process, quick degradation velocity and limited mechanical strength of the fibrin-based hydrogels all need to be addressed for organ 3D bioprinting with anti-suture capability. Especially, when the fibrinogen solution was printed alone with cells, the rapid gelation process is difficult to control to form stable 3D constructs. An effective solution is to blend the fibrinogen solution with other chemical crosslinkable natural polymers, such as gelatin, alginate, hyaluronan, and collagen.

Like alginate, the first report of fibrin in 3D bioprinting is in 2007 by Professor X. Wang, in which fibrinogen was acted as an additive of the gelatin based hydrogel for hepatic tissue or vascularized hepatic tissue manufacturing [21]. The physical blending and chemical crosslinking fibrinogen with gelatin molecules can evidently avoid the collapse of the 3D printed constructs, slow down the polymer degradation rate and amend the structural stability. Nowadays, the physical blending and chemical crosslinking have rapidly expanded to much more complicated hybrid polymeric 'bioinks', such as the gelatin/fibrinogen/alginate, gelatin/fibrinogen/chitosan gelatin/fibrinogen/hyaluronan, and gelatin/fibrinogen/hyaluronan/glycerol (dimethyl sulfoxide, dextran-40, or heparin) $[54,55,61,62]$. 
The combination of physical blending and chemical crosslinking is a successful way to make the natural polymeric 'bioinks' to fulfill various requirements for tissue/organ 3D bioprinting, such as providing adequate benign environments for cell encapsulation during and after the printing processes.

Among all the fibrin containing 'bioinks', gelatin/alginate/fibrin has been chosen as an optimal constituent for complicated organ 3D bioprinting [54,55,61,62]. Partly due to that the composite gelatin/alginate/fibrin hydrogel can be double reinforced by polymerizing the fibrinogen molecules using thrombin and crosslinking the alginate molecules using $\mathrm{CaCl}_{2}$. After the double chemical crosslinking, the gelatin/alginate/fibrin hydrogel has exceptional mechanical properties, excellent cytocompatibilities, and extraordinary physiological functions. Correspondingly, the compressive and elastic modulus of the 3D bioprinted constructs have been strengthened remarkably [126].

An outstanding character of the gelatin/alginate/fibrin hydrogel is that all the cells and bioactive agents can be incorporated and 3D bioprinted without reducing their bioactivities. Stem cells, such as adipose-derived stem cells (ADSCs), can be induced into various target tissues/organs with proper growth factor engagement $[54,55,61,62]$. It is regarded as a milestone in large vascularized organ manufacturing fields. Until now, stem cells have been regarded as the ideal cell types for large scale-up vascularized organ 3D bioprinting [127-129].

Recently, fibrin has been used in some other 3D bioprinting technologies, such as skin and adipose organ engineering, with excellent cell and tissue compatibilities $[106,130]$. For example, Hakam et al. reported the gelatin/fibrin hydrogel for skin bioprinting. The hybrid hydrogel with 1:1 $v / v$ gelatin/fibrin ratio was selected as an optimal composition to evaluate the water/glucose absorption capability, polymer degradation rate, mechanical compression situation and water vapor transmission. As a result, this hybrid hydrogel could provide the cell pellets within $200-250 \mu \mathrm{m}$ in diameter, with better cell viability [105]. Additionally, in situ printing of fibrin-collagen hydrogels with amniotic fluid-derived stem cells could result in increased wound closure rates, as well as increased vascularization of the regenerating tissues [131].

\subsection{Chitosan}

Chitosan is a natural polysaccharide (derived from shrimp shell) formed by deacetylation of chitin, which has been applied in many biomedical fields, such as bone, skin and cartilage repair, due to its low or non-toxic, antibiotic and biodegradable properties (Figure 6) [132-138]. Chitosan can be biodegraded by lysozymes into amino-sugars $[119,139]$. Similar to alginate and hyaluronan, the poor mechanical strengths and slow gelation properties of the chitosan solutions have obvious hindered its application in organ $3 \mathrm{D}$ printing areas.

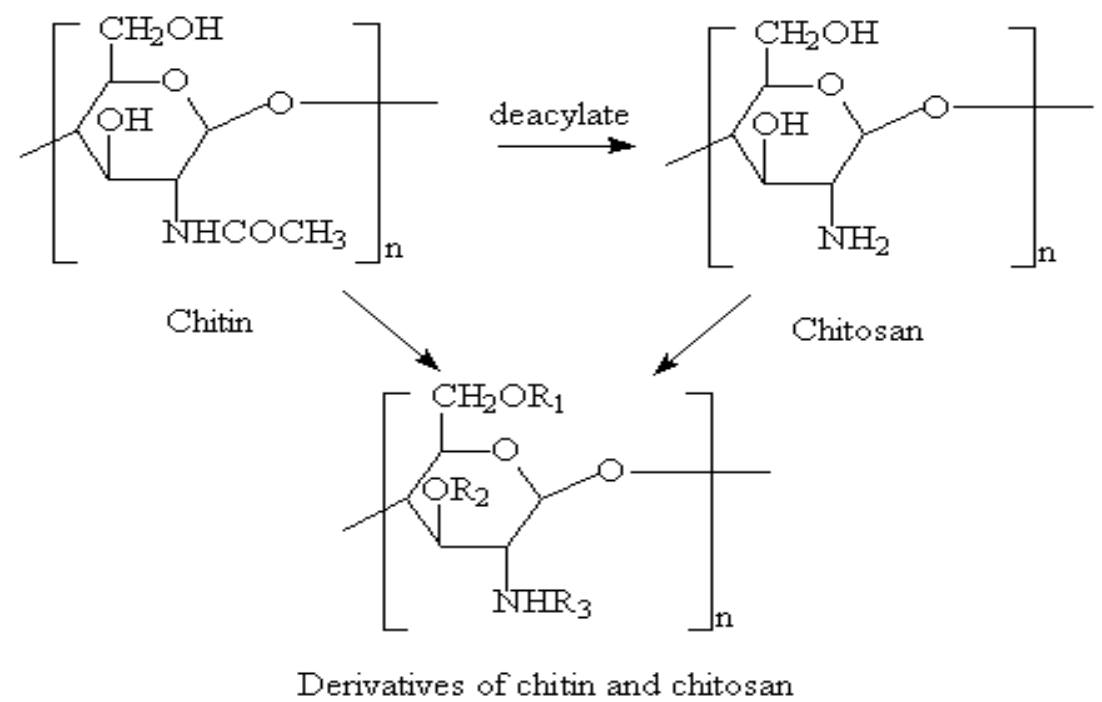

Figure 6. Molecular structure of chitosan [122]. 
Similar stabilization strategies have also been used in chitosan 3D bioprinting by Professor X. Wang [97]. The mechanical properties can be intensified as expected by physical blending and chemical crosslinking chitosan with other supportive polymers, such as alginate, gelatin and collagen [97]. As a normal approach, high viscosity of chitosan is recommended in the extrusion-based hybrid polymeric hydrogel 3D bioprinting technologies. Recently, collagen/chitosan, alginate/chitosan, gelatin/alginate/chitosan have been frequently utilized as 'bioinks' in various organ 3D bioprinting areas. Exceptionally, chitosan itself can be chemically modified to improve its printability at suitable $\mathrm{pH}(7-7.4)$ with no detriments on its biocompatibility and biodegradability.

\subsection{Agarose}

Agarose derived from the cell wall of red algae is a naturally linear polysaccharide that mainly composes of $\beta$-D-galactopyranose and 3,6-anhydro- $\alpha$-L-galactopyranose (Figure 7) [140]. It is another thermal-response natural polymer besides gelatin with a liquefaction temperature approximate $30{ }^{\circ} \mathrm{C}$, which is suitable for the extrusion-based 3D bioprinting processes [141].

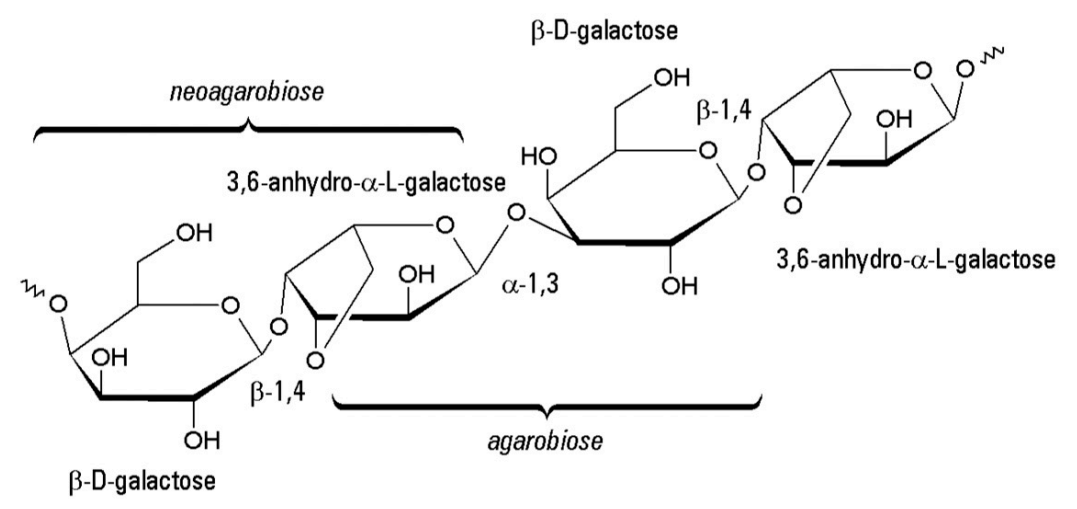

Figure 7. Molecular structure of agarose.

Unlike gelatin, the gelling temperature of agarose depends on the polymer concentration. Agarose has no cell adhesion motifs and the cell encapsulation capacity is poor. It is usually used as bacterium culture substrates. Recently, it appears as a modified polymer in 3D bioprinting by blending or crosslinking with other supportive components in a hybrid polymeric hydrogel [142]. For example, an optimal composite hydrogel with 50\% $v / v$ Matrigel and 3\% $w / v$ agarose can support the growth and adhesion of intestinal epithelial cells, especially at a constant temperature of $37^{\circ} \mathrm{C}$ [143].

\subsection{Decellularized Extracellular Matrix (dECM)}

Decellularized extracellular matrix (dECM) is a mixture of natural polymers, which is obtained from decellularization of different animal tissues, such as skin, small intestinal submucosa, and liver [144]. After decellularization, the composition and topology of the original tissues can be highly remained, which can provide tissue-specific microenvironments for preserving cell-specific functions. The decellularization processes can be either physical, chemical, biochemical (e.g., enzymatic) or their combinations, which can affect the final dECM compositions [145]. The resulted dECM-based solutions gel immediately beyond $15^{\circ} \mathrm{C}$ and form physically crosslinked hydrogels. It was reported that, procine-liver-derived dECM could be used as a functional substrate for hepatocyte culture. The liver-specific AECM could maintain hepatocyte functions through albmin secretion, mRNA expression of bilesalt export pump (BSEP) and sodium taurocholate co-transporting polypeptide (NTCP), which was regarded as a promising scaffold material in tissue 3D bioprinting [146].

For organ 3D bioprinting, dECM can provide cells with customized milieus. Due to its low viscosity, dECM 'bioinks' often need other supportive polymers to provide basic 3D printability and shape fidelity. For example, an adipose-derived dECM/polycaprolactone (PCL) hydrogel with 
encapsulated ADSCs has been printed by a multi-head tissue building system and resulted in a high cell viability $(>90 \%)$ [147].

Currently, there is a growing interest on using dECM-derived 'bioinks' for a variety of customized bioartificial organ 3D bioprinting, both in academic and industrial settings. Some dECM-derived 'bioinks' have been examined as potential replacements for clinical applications. Nervetheless, the clinical success depends largely on how well the mechanical property preserved. Although dECM has remarkable advantages for tissue/organ-specific function preservation, it still faces many other challenges for complex organ 3D bioprinting. Firstly, it is difficult to efficiently remove antigenic epitopes to eliminate immune responses created by the allogeneic or xenogeneic recipients of dECMs. Secondly, residual DNA or nuclear materials are retained more or less in the dECMs, which probably affects the encapsulated cell behaviors. Lastly, the extremely weak mechanical properties, poor construction resolution, remarkable shape shrinkage and rapid degradation rate are major problems to be solved in the future [148].

\section{Typical Organ 3D Bioprinting Technologies}

Unlike tissues, which can be printed using simple 3D printers and 'bioinks'. All the organs have large scale-up heterogeneous cell/tissue components with complex vascular, neural or lymphatic networks. The complexity of the geometrical architecture and material constituent determines the difficulty levels of the organ 3D bioprinting technologies.

Generally, natural polymers as the main component of various 'bioinks' should meet several basic requirements for a successful organ 3D bioprinting as well as clinical applications: (1) biocompatible (i.e., nontoxic or no obvious toxicity); (2) biodegradable (vs nonbiodegradable polymers can be used as supportive structures); (3) biostable with strong enough mechanical strength; (4) bioprintable (processable); (5) biostorable in a proper period.

In 2008, a double-nozzle extrusion-based 3D bioprinter was innovated at the center of organ manufacturing in Tsinghua University, professor Wang's laboratory (Figure 8) [88,89]. Using this technology, two cell types with large population of cells have been simultaneously printed into large scale-up living organs (Figure $8 \mathrm{~b}-\mathrm{h}$ ). With the updated hard- and software, both the hierarchical branched vascular templates and grid go-through (i.e., interconnected) channels have been properly integrated into the living organs under the instructions of the CAD models [149-151]. Much more complex structures can be accomplished through imitating those of the natural organs [152-155].

These results have certified that by proper polymeric 'bioink' and 3D bioprinter design, the gelatin-based hydrogels in the solid 3D constructs can serve as optimal 3D substrates that engender nutrient and growth factor infiltration, multi-cellular communication (such as endothelization or vascularization), and new organ generation (i.e., a special program that is relevant to tissue colonization and organ morphologies). As those in the single-nozzle/syringe 3D bioprinting, ADSCs entrapped in the gelatin-based hydrogels can be engaged into heterogeneous tissues for large vascular organ manufacturing. Primary hepatocytes can form functional parenchymal tissues beside the hierarchical vascular and/or neural networks in the 3D constructs. This integration of natural polymers with multi-nozzle extrusion-based 3D printing technologies has reshaped the healthcare landscapes, and will unavoidably change the lives of countless individuals and bring huge benefit to the whole human beings [156,157]. 

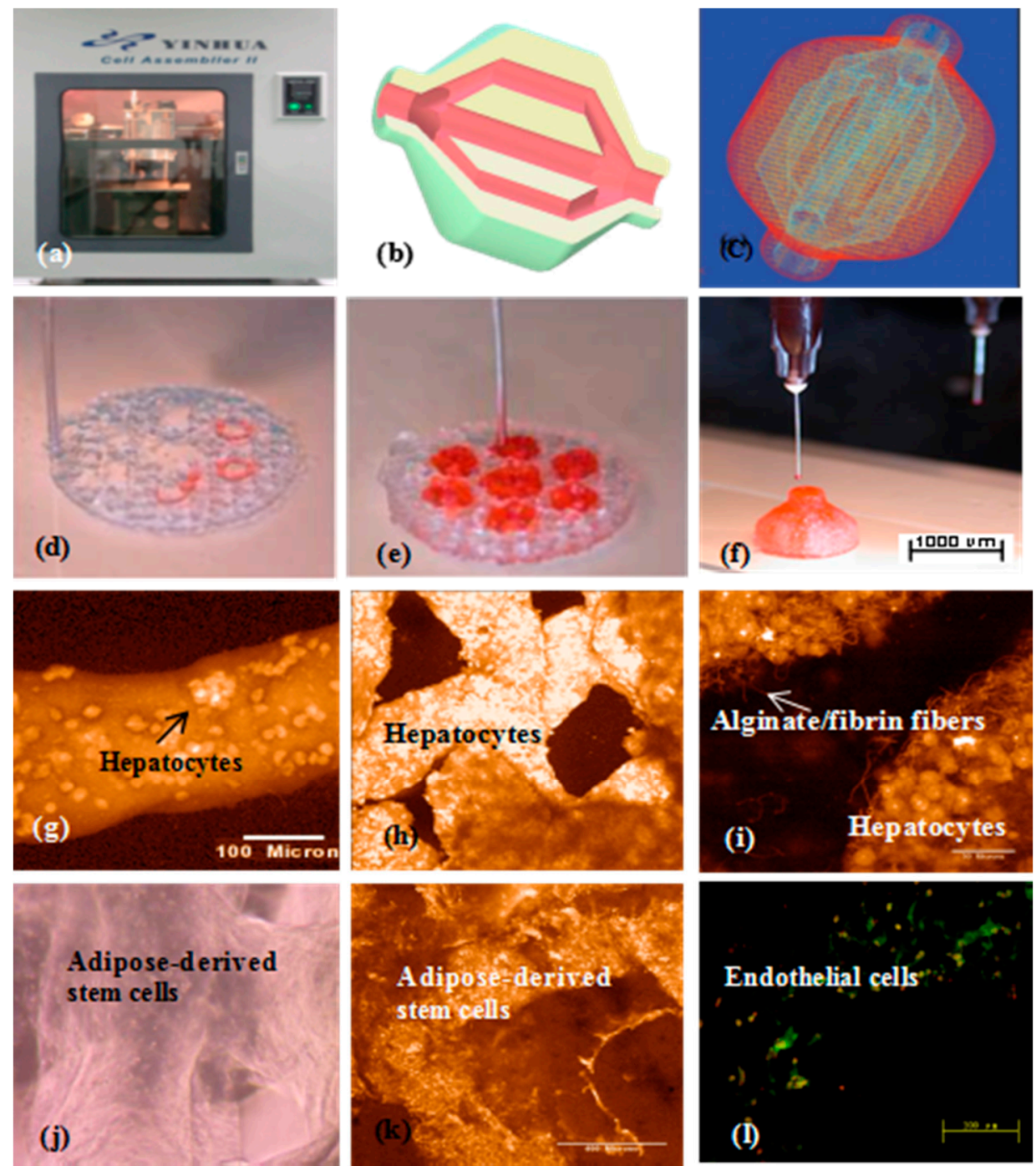

Figure 8. A large scale-up 3D printed vascularized organ (i.e., adipose tissue) constructed through the double-nozzle (syringe) 3D bioprinter: (a) The 3D printer; (b) a computer-aided design (CAD) model containing a branched vascular network; (c) a CAD model containing the branched vascular network; (d) 3D bioprinting with ADSCs encapsulated in the gelatin/alginate/fibrin hydrogel and hepatocytes encapsulated in the gelatin/alginate/chitosan hydrogel before epidermal growth factor (EGF) engagement, immunostaining with pyrindine (PI) for cell nuclei in red; (e) several 3D printed layers of the construct; (f) half an ellipse of the 3D construct; (g) hepatocytes in the gelatin-based hydrogel after 3D bioprinting; (h) hepatocytes in a 3D printed fiber; (i) hepatocytes in a grid structure; (j) hepatocytes in a magnificant image, the crosslinked alginate/fibrin fibers can be observed; (k) ADSCs in the gelatin-based hydrogel after 3D bioprinting before growth factor engagement; (1) ADSCs in the gelatin-based hydrogel after 3D bioprinting after EGF engagement, CD31 immunofluorescence staining endothelial cells on day 10 after EGF engagement. Most cells located on the walls of the go-through channels were CD31 positive cells with bright color (i.e., mature endothelial cells).

\section{Conclusions}

Organ manufacturing is an interdisciplinary field that needs to integrate a large scope of talents, such as biological, material, chemical, physical, mechanical, medical and clinical. The emerging of 3D bioprinting technologies is the integration results of mechanics with biomaterials and other sciences and technologies, such as biology, chemistry, physics, informatics, computer and medicine. Natural polymers, such as gelatin, alginate, hyaluronic acid, fibrinogen, and their combinations, have played several critical roles in various tissue/organ 3D bioprinting technologies with profound 
influence in cellular/biomolecular selfaction/interaction, histogenesis formation/modulation and organ construction/maturation. These polymers acted as the main components of variety 'bioinks' are essential for bioartificial organ 3D bioprinting to provide cell-, tissue- and organ-specific structures and functions. However, the notorious poor mechanical properties of the natural polymeric 'bioinks' have greatly limited their usage in complex organ 3D printing with anti-suture structures, such as the hierarchical vascular, neural and lymphatic networks. Physical blending, chemical crosslinking and the combination of both natural and synthetic polymers are effective ways to solve the geometrical, mechanical, structural, physiological and clinical problems. The better understanding of the physical, chemical and biological characteristics of the natural polymers helps to build much more complex tissues and organs with much more specific structures and functions, such as the glomeruli in the kidney and biliary networks (or biliary ducts) in the liver. This is particularly important for future individual or customized organ reverse engineering/manufacturing with predefined essential architectures, diversified material compositions, specialized cellular/biomolecular activities and expected physiological/biomedical functionalities.

Author Contributions: F.L. wrote the main content; X.W. revise the manuscript; and Q.C., C.L., Q.A., X.T., J.F., and H.T. contributed some detailed techniques.

Acknowledgments: The work was supported by grants from the National Natural Science Foundation of China (NSFC) (nos. 81571832, 81271665, 31600793, 81571919) and the 2017 Discipline Promotion Project of China Medical University (CMU) (no. 3110117049).

Conflicts of Interest: The authors declare no conflict of interest. The founding sponsors had no role in the design of the study; in the collection, analyses, or interpretation of data; in the writing of the manuscript, and in the decision to publish the results.

\section{References}

1. Widmaier, E.P.; Raff, H.; Strang, K.T. The Mechanisms of Body Function. In Vander's Human Physiology; McGraw-Hill: New York, NY, USA, 2012; pp. 250-291.

2. Allemani, C.; Weir, H.K.; Carreira, H.; Harewood, R.; Spika, D.; Wang, X.S.; Bannon, F.; Ahn, J.V.; Johnson, C.J.; Bonaventure, A.; et al. CONCORD Working Group. Global surveillance of cancer survival 1995-2009: Analysis of individual data for 25,676,887 patients from 279 population-based registries in 67 countries (CONCORD-2). Lancet 2015, 385, 977-1010. [CrossRef]

3. Patrick, C.W., Jr. Adipose tissue engineering: The future of breast and soft tissue reconstruction following tumor resection. Semin. Surg. Oncol. 2000, 19, 302-311. [CrossRef]

4. Vasir, B.; Reitz, P.; Xu, G.; Sharma, A.; Bonner, W.S.; Weir, G.C. Effects of diabetes and hypoxia on gene markers of angiogenesis (HGF, cMET, uPA and uPAR, TGF- $\alpha$, TGF- $\beta$, bFGF and Vimentin) in cultured and transplanted rat islets. Diabetologia 2000, 43, 763-768. [CrossRef] [PubMed]

5. Yelin, E.; Weinstein, S.; King, T. The burden of musculoskeletal diseases in the United States. Semin. Arthritis Rheum. 2016, 46, 259-260. [CrossRef] [PubMed]

6. Dalal, A.R. Philosophy of organ donation: Review of ethical facets. World J. Transplant. 2015, 24, 44-51. [CrossRef] [PubMed]

7. Langer, R.; Vacanti, J.P. Tissue engineering. Science 1993, 260, 920-926. [CrossRef] [PubMed]

8. Wang, X.; Yan, Y.; Lin, F.; Xiong, Z.; Wu, R.; Zhang, R.; Lu, Q. Preparation and characterization of a collagen/chitosan/heparin matrix for an implantable bioartificial liver. J. Biomater. Sci. Polym. Ed. 2005, 16, 1063-1080. [CrossRef] [PubMed]

9. Moniaux, N.; Faivre, J.A. Reengineered liver for transplantation. J. Hepatol. 2011, 54, 386-387. [CrossRef] [PubMed]

10. Mao, A.S.; Mooney, D.J. Regenerative medicine: Current therapies and future directions. Proc. Natl. Acad. Sci. USA 2015, 112, 14452-14459. [CrossRef] [PubMed]

11. Hanauer, N.; Latreille, P.L.; Alsharif, S.; Banquy, X. 2D, 3D and 4D active compound delivery in tissue engineering and regenerative medicine. Curr. Pharm. Des. 2015, 21, 1506-1516. [CrossRef] [PubMed]

12. Wang, X.; Yan, Y.; Zhang, R. Rapid prototyping as tool for manufacturing bioartificial livers. Trends Biotechnol. 2007, 25, 505-513. [CrossRef] [PubMed] 
13. Wang, X. Intelligent freeform manufacturing of complex organs. Artif. Org. 2012, 36, 951-961. [CrossRef] [PubMed]

14. Wang, X.; Yan, Y.; Zhang, R. Recent trends and challenges in complex organ manufacturing. Tissue Eng. Part B 2010, 16, 189-197. [CrossRef] [PubMed]

15. Ott, H.C.; Matthiesen, T.S.; Goh, S.K.; Black, L.D.; Kren, S.M.; Netoff, T.I.; Taylor, D.A. Perfusion-decellularized matrix: Using nature's platform to engineer a bioartificial heart. Nat. Med. 2008, 14, 213-221. [CrossRef] [PubMed]

16. Wang, X.; Huang, Y.W.; Liu, C. A combined rotational mold for manufacturing a functional liver system. J. Bioact. Compat. Polym. 2015, 39, 436-451. [CrossRef]

17. Lei, M.; Wang, X. Biodegradable polymers and stem cells for bioprinting. Molecules 2016, 21, 539. [CrossRef] [PubMed]

18. Bonandrini, B.; Figliuzzi, M.; Papadimou, E.; Morigi, M.; Perico, N.; Casiraghi, F.; Sangalli, F.; Conti, S.; Benigni, A.; Remuzzi, A. Recellularization of well-preserved acellular kidney scaffold using embryonic stem cells. Tissue Eng. Part A 2014, 20, 1486. [CrossRef] [PubMed]

19. Ozbolat, I.T.; Hospodiuk, M. Current advances and future perspectives in extrusion-based bioprinting. Biomaterials 2016, 76, 321-343. [CrossRef] [PubMed]

20. Liu, F.; Liu, C.; Chen, Q.; Ao, Q.; Tian, X.; Fan, J.; Tong, H.; Wang, X. Progress in organ 3D bioprinting. Int. J. Bioprint. 2018, 4, 1-15. [CrossRef]

21. Wang, X.; Tuomi, J.; Mäkitie, A.A.; Poloheimo, K.-S.; Partanen, J.; Yliperttula, M. The integrations of biomaterials and rapid prototyping techniques for intelligent manufacturing of complex organs. In Advances in Biomaterials Science and Applications in Biomedicine; Lazinica, R., Ed.; In Tech: Rijeka, Croatia, 2013; pp. 437-463.

22. Wang, X.; Yan, Y.; Zhang, R. Gelatin-based hydrogels for controlled cell assembly. In Biomedical Applications of Hydrogels Handbook; Ottenbrite, R.M., Ed.; Springer: New York, NY, USA, 2010; pp. 269-284.

23. Nair, L.S.; Laurencin, C.T. Biodegradable polymers as biomaterials. Prog. Polym. Sci. 2007, 32, 762-798. [CrossRef]

24. Derby, B. Printing and prototyping of tissues and scaffolds. Science 2012, 338, 921-926. [CrossRef] [PubMed]

25. Toh, W.S.; Loh, X.J. Advances in hydrogel delivery systems for tissue regeneration. Mater. Sci. Eng. C Mater. Biol. Appl. 2014, 45, 690-697. [CrossRef] [PubMed]

26. Hou, R.; Nie, L.; Du, G.; Xiong, X.; Fu, J. Natural polysaccharides promote chondrocyte adhesion and proliferation on magnetic nanoparticle/PVA composite hydrogels. Colloids Surf. B 2015, 132, 146-154. [CrossRef] [PubMed]

27. Billiet, T.; Vandenhaute, M.; Schelfhout, J.; Van Vlierberghe, S.; Dubruel, P. A review of trends and limitations in hydrogel-rapid prototyping for tissue engineering. Biomaterials 2015, 33, 6020-6041. [CrossRef] [PubMed]

28. Li, C.; Faulkner-Jones, A.; Dun, A.R.; Jin, J.; Chen, P.; Xing, Y.; Yang, Z.; Li, Z.; Shu, W.; Liu, D.; et al. Rapid formation of a supramolecular polypeptide-DNA hydrogel for in situ three-dimensional multilayer bioprinting. Angew. Chem. Int. Ed. Engl. 2015, 54, 3957-3961. [CrossRef] [PubMed]

29. Doppalapudi, S.; Jain, A.; Domb, A.J.; Khan, W. Biodegradable polymers for targeted delivery of anti-cancer drugs. Expert Opin. Drug Deliv. 2016, 13, 891-909. [CrossRef] [PubMed]

30. Fedorovich, N.E.; Swennen, I.; Girones, J.; Moroni, L.; van Blitterswijk, C.A.; Schacht, E.; Alblas, J.; Dhert, W.J. Evaluation of photocrosslinked lutrol hydrogel for tissue printing applications. Biomacromolecules 2009, 10, 1689-1696. [CrossRef] [PubMed]

31. Li, S.; Yan, Y.; Xiong, Z.; Weng, C.; Zhang, R.; Wang, X. Gradient hydrogel construct based on an improved cell assembling system. J. Bioact. Compat. Polym. 2009, 24, 84-99. [CrossRef]

32. Zhang, Y.; Yu, Y.; Ozbolat, I.T. Direct bioprinting of vessel-like tubular microfluidic channels. J. Nanotechnol. Eng. Med. 2013, 4, 210011-210017. [CrossRef]

33. Markstedt, K.; Mantas, A.; Tournier, I.; Martínez Ávila, H.; Hägg, D.; Gatenholm, P. 3D bioprinting human chondrocytes with nanocellulose-alginate bioink for cartilage tissue engineering applications. Biomacromolecules 2015, 16, 1489-1496. [CrossRef] [PubMed]

34. Ozbolat, I.T.; Chen, H.; Yu, Y. Development of "Multi-arm Bioprinter" for hybrid biofabrication of tissue engineering constructs. Robot. Comput. Integr. Manuf. 2014, 30, 295-304. [CrossRef] 
35. Xavier, J.R.; Thakur, T.; Desai, P.; Jaiswal, M.K.; Sears, N.; Cosgriff-Hernandez, E.; Kaunas, R.; Gaharwar, A.K. Bioactive nanoengineered hydrogels for bone tissue engineering: A growth-factor-free approach. ACS Nano 2015, 9, 3109-3118. [CrossRef] [PubMed]

36. Xu, C.; Zhang, M.; Huang, Y.; Ogale, A.; Fu, J.; Markwald, R.R. Study of droplet formation process during drop-on-demand inkjetting of living cell-laden bioink. Langmuir 2014, 30, 9130-9138. [CrossRef] [PubMed]

37. Lee, V.; Lanzi, A.; Ngo, H.; Yoo, S.-S.; Vincent, P.; Dai, G. Generation of multi-scale vascular network system within 3D hydrogel using 3D bio-printing technology. Cell. Mol. Bioeng. 2014, 7, 460-472. [CrossRef] [PubMed]

38. Lee, V.K.; Kim, D.Y.; Ngo, H.; Lee, Y.; Seo, L.; Yoo, S.; Vincent, P.A.; Dai, G. Creating perfused functional vascular channels using 3D bio-printing technology. Biomaterials 2014, 35, 8092-8102. [CrossRef] [PubMed]

39. Thein-Han, W.; Xu, H.H.K. Prevascularization of a gas-foaming macroporous calcium phosphate cement scaffold via coculture of human umbilical vein endothelial cells and osteoblasts. Tissue Eng. Part A 2013, 19, 1675-1685. [CrossRef] [PubMed]

40. Rutz, A.L.; Hyland, K.E.; Jakus, A.E.; Burghardt, W.R.; Shah, R.N. A multi-material bioink method for 3D printing tunable, cell-compatible hydrogels. Adv. Mater. 2015, 27, 1607-1614. [CrossRef] [PubMed]

41. Huang, T.Q.; Qu, X.; Liu, J.; Chen, S. 3D printing of biomimetic microstructures for cancer cell migration. Biomed. Microdevices 2014, 16, 127-132. [CrossRef] [PubMed]

42. Pawar, S.N.; Edgar, K.J. Alginate derivatization: A review of chemistry, properties and applications. Biomaterials 2012, 33, 3279-3305. [CrossRef] [PubMed]

43. Lee, K.Y.; Mooney, D.J. Alginate: Properties and biomedical applications. Prog. Polym. Sci. 2012, 37, $106-126$. [CrossRef] [PubMed]

44. Choi, Y.-J.; YI, H.-G.; Kim, S.-W.; Cho, D.-W. 3D cell printed tissue analogues: A new platform for theranostics. Theranostics 2017, 7, 3118-3137. [CrossRef] [PubMed]

45. Tønnesen, H.H.; Karlsen, J. Alginate in drug delivery systems. Drug Dev. Ind. Pharm. 2002, 28, 621-630. [CrossRef] [PubMed]

46. Drury, J.L.; Dennis, R.G.; Mooney, D.J. The tensile properties of alginate hydrogels. Biomaterials 2004, 25, 3187-3199. [CrossRef] [PubMed]

47. Stanton, M.M.; Samitier, J.; Sánchez, S. Bioprinting of 3D hydrogels. Lab Chip 2015, 15, 3111-3115. [CrossRef] [PubMed]

48. Axpe, E.; Oyen, M.L. Applications of alginate-based bioinks in 3D bioprinting. Int. J. Mol. Sci. 2016, 17. [CrossRef] [PubMed]

49. Park, J.; Lee, S.J.; Chung, S.; Lee, J.H.; Kim, W.D.; Lee, J.Y.; Park, S.A. Biofunctional rapid prototyping for tissue-engineering applications: 3D bioplotting versus 3D printing. J. Polym. Sci. Part A Polym. Chem. 2004, 42, 624-638.

50. Ahn, S.; Lee, H.; Bonassar, L.J.; Kim, G. Cells (MC3T3-E1)-laden alginate scaffolds fabricated by a modified solid-freeform fabrication process suppliemented with an aerosol spraying. Biomacromolecules 2012, 13, 2997-3003. [CrossRef] [PubMed]

51. Yan, Y.; Wang, X.; Xiong, Z.; Liu, H.; Liu, F.; Lin, F.; Wu, R.; Zhang, R.; Lu, Q. Direct construction of a three-dimensional structure with cells and hydrogel. J. Bioact. Compat. Polym. 2005, 20, 259-269. [CrossRef]

52. Yao, R.; Zhang, R.; Wang, X. Design and evaluation of a cell microencapsulating device for cell assembly technology. J. Bioact. Compat. Polym. 2009, 24, 48-62. [CrossRef]

53. Yao, R.; Zhang, R.; Yan, Y.; Wang, X. In vitro angiogenesis of 3D tissue engineered adipose tissue. J. Bioact. Compat. Polym. 2009, 24, 5-24.

54. Park, J.; Lee, S.J.; Chung, S.; Lee, J.H.; Kim, W.D.; Lee, J.Y.; Park, S.A. Cell-laden 3D bioprinting hydrogel matrix depending on different compositions for soft tissue engineering: Characterization and evaluation. Mater. Sci. Eng. C Mater. Biol. Appl. 2017, 71, 678-684. [CrossRef] [PubMed]

55. Kong, H.J.; Kaigler, D.; Kim, K.; Mooney, D.J. Controlling rigidity and degradation of alginate hydrogels via molecular weight distribution. Biomacromolecules 2004, 5, 1720-1727. [CrossRef] [PubMed]

56. Wong, T.Y.; Preston, L.A.; Schiller, N.L. ALGINATE LYASE: Review of major sources and enzyme characteristics, structure-function analysis, biological roles, and applications. Annu. Rev. Microbiol. 2000, 54, 289-340. [CrossRef] [PubMed]

57. Sui, S.; Wang, X.; Liu, P.; Yan, Y.; Zhang, R. Cryopreservation of cells in 3D constructs based on controlled cell assembly processes. J. Bioact. Compat. Polym. 2009, 24, 473-487. [CrossRef] 
58. Wang, X.; Paloheimo, K.-S.; Xu, H.; Liu, C. Cryopreservation of cell/hydrogel constructs based on a new cell-assembling technique. J. Bioact. Compat. Polym. 2010, 25, 634-653. [CrossRef]

59. Wang, X.; Xu, H. Incorporation of DMSO and dextran-40 into a gelatin/alginate hydrogel for controlled assembled cell cryopreservation. Cryobiology 2010, 61, 345-351. [CrossRef] [PubMed]

60. Li, S.; Xiong, Z.; Wang, X.; Yan, Y.; Liu, H.; Zhang, R. Direct fabrication of a hybrid cell/hydrogel construct by a double-nozzle assembling technology. J. Bioact. Compat. Polym. 2009, 24, 249-265.

61. Xu, M.; Yan, Y.; Liu, H.; Yao, Y.; Wang, X. Control adipose-derived stromal cells differentiation into adipose and endothelial cells in a 3-D structure established by cell-assembly technique. J. Bioact. Compat. Polym. 2009, 24, 31-47. [CrossRef]

62. Xu, M.; Wang, X.; Yan, Y.; Yao, R.; Ge, Y. A cell-assembly derived physiological 3D model of the metabolic syndrome, based on adipose-derived stromal cells and a gelatin/alginate/fibrinogen matrix. Biomaterials 2010, 31, 3868-3877. [CrossRef] [PubMed]

63. Shim, J.H.; Lee, J.S.; Kim, J.Y.; Cho, D.W. Bioprinting of a mechanically enhanced three-dimensional dual cell-laden construct for osteochondral tissue engineering using a multi-head tissue/organ building system. J. Micromech. Microeng. 2012, 22, 085014. [CrossRef]

64. Yu, Y.; Zhang, Y.; Martin, J.A.; Ozbolat, I.T. Evaluation of cell viability and functionality in vessel-like bioprintable cell-laden tubular channels. J. Biomech. Eng. 2013, 135, 91011. [CrossRef] [PubMed]

65. Duan, B.; Hockaday, L.A.; Kang, K.H.; Butcher, J.T. 3D bioprinting of heterogeneous aortic valve conduits with alginate/gelatin hydrogels. J. Biomed. Mater. Res. Part A 2013, 101A, 1255-1264. [CrossRef] [PubMed]

66. Chung, J.Y.; Naficy, S.; Yue, Z.; Kapsa, R.; Quigley, A.; Moulton, S.; Wallace, G. Bio-ink properties and printability for extrusion printing living cells. Biomater. Sci. 2013, 1, 763-773. [CrossRef]

67. Wang, X.; He, K.; Zhang, W. Optimizing the fabrication processes for manufacturing a hybrid hierarchical polyurethane-cell/hydrogel construct. J. Bioact. Compat. Polym. 2013, 28, 303-319. [CrossRef]

68. Huang, Y.; He, K.; Wang, X. Rapid Prototyping of a hybrid hierarchical polyurethane-cell/hydrogel construct for regenerative medicine. Mater. Sci. Eng. C 2013, 33, 3220-3229. [CrossRef] [PubMed]

69. Wang, J. Development of a Combined 3D Printer and Its Application in Complex Organ Construction. Master's Thesis, Tsinghua University, Beijing, China, 2014.

70. Sarker, B.; Singh, R.; Silva, R.; Roether, J.A.; Kaschta, J.; Detsch, R.; Schubert, D.W.; Cicha, I.; Boccaccini, A.R. Evaluation of fibroblasts adhesion and proliferation on alginate-gelatin crosslinked hydrogel. PLoS ONE 2014, 9, e107952. [CrossRef] [PubMed]

71. Jia, J.; Richards, D.J.; Pollard, S.; Tan, Y.; Rodriguez, J.; Visconti, R.P.; Trusk, T.C.; Yost, M.J.; Yao, H.; Markwald, R.R.; et al. Engineering alginate as bioink for bioprinting. Acta Biomater. 2014, 10, 4323-4331. [CrossRef] [PubMed]

72. Zhang, W.; Lian, Q.; Li, D.; Wang, K.; Hao, D.; Bian, W.; He, J.; Jin, Z. Cartilage repair and subchondral bone migration using 3D printing osteochondral composites: A one-year-period study in rabbit trochlea. Biomed. Res. Int. 2014, 5, 23-28. [CrossRef] [PubMed]

73. Ahn, S.H.; Lee, H.J.; Lee, J.S.; Yoon, H.; Chun, W.; Kim, G.H. A novel cell-printing method and its application to hepatogenic differentiation of human adipose stem cell-embedded mesh structures. Sci. Rep. 2015, 5, 13427. [CrossRef] [PubMed]

74. Kundu, J.; Shim, J.H.; Jang, J.; Kim, S.W.; Cho, D.W. An additive manufacturing-based PCL-alginate-chondrocyte bioprinted scaffold for cartilage tissue engineering. J. Tissue Eng. Regen. Med. 2015, 9, 1286-1297. [CrossRef] [PubMed]

75. Colosi, C.; Shin, S.R.; Manoharan, V.; Massa, S.; Costantini, M.; Barbetta, A.; Dokmeci, M.R.; Dentini, M.; Khademhosseini, A. Microfluidic bioprinting of heterogeneous 3D tissue constructs using low-viscosity bioink. Adv. Mater. 2016, 28, 677-684. [CrossRef] [PubMed]

76. Zhao, X.; Wang, X. Preparation of an adipose-derived stem cell/fibrin-poly(DL-lactic-co-glycolic acid) construct based on a rapid prototyping technique. J. Bioact. Compat. Polym. 2013, 28, 191-203. [CrossRef]

77. Zhao, X.; Du, S.; Chai, L.; Xu, Y.; Liu, L.; Zhou, X.; Wang, J.; Zhang, W.; Liu, C.-H.; Wang, X. Anti-cancer drug screening based on an adipose-derived stem cell/hepatocyte 3D printing technique. J. Stem Cell Res. Ther. 2015, 5. [CrossRef]

78. Zhou, X.; Liu, C.; Wang, X. A 3D bioprinting liver tumor model for drug screening. World J. Pharm. Pharm. Sci. 2016, 5, 196-213. 
79. Izadifar, Z.; Chang, T.; Kulyk, W.; Chen, X.; Eames, B.F. Analyzing biological performance of 3D-printed, cell-impregnated hybrid constructs for cartilage tissue engineering. Tissue Eng. Part C Methods 2016, 22, 173-188. [CrossRef] [PubMed]

80. Daly, A.C.; Cunniffe, G.M.; Sathy, B.N.; Jeon, O.; Alsberg, E.; Kelly, D.J. 3D bioprinting of developmentally inspired templates for whole bone organ engineering. Adv. Healthc. Mater. 2016, 5, 2353-2362. [CrossRef] [PubMed]

81. Jia, W.; Gungor-Ozkerim, P.S.; Zhang, Y.S.; Yue, K.; Zhu, K.; Liu, W.; Pi, Q.; Byambaa, B.; Dokmeci, M.R.; Shin, S.R.; et al. Direct 3D bioprinting of perfusable vascular constructs using a blend bioink. Biomaterials 2016, 106, 58-68. [CrossRef] [PubMed]

82. Liu, J.; Chi, J.; Wang, K.; Liu, X.; Gu, F. Full-thickness wound healing using 3D bioprinted gelatin-alginate scaffolds in mice: A histopathological study. Int. J. Clin. Exp. Pathol. 2016, 9, 11197-11205.

83. Luo, Y.X.; Luo, G.L.; Gelinsky, M.; Huang, P.; Ruan, C.S. 3D bioprinting scaffold using alginate/polyvinyl alcohol bioinks. Mater. Lett. 2017, 189, 295-298. [CrossRef]

84. Bendtsen, S.T.; Quinnell, S.P.; Wei, M. Development of a novel alginate-polyvinyl alcohol-hydroxyapatite hydrogel for 3D bioprinting bone tissue engineered scaffolds. J. Biomed. Mater. Res. Part A 2017, 105, 1457-1468. [CrossRef] [PubMed]

85. Bendtsen, S.T.; Wei, M. In vitro evaluation of 3D bioprinted tri-polymer network scaffolds for bone tissue regeneration. J. Biomed. Mater. Res. Part A 2017, 105, 3262-3272. [CrossRef] [PubMed]

86. Yu, H.Y.; Ma, D.D.; Wu, B.L. Gelatin/alginate hydrogel scaffolds prepared by 3D bioprinting promotes cell adhesion and proliferation of human dental pulp cells in vitro. J. South. Med. Univ. 2017, 37, 668.

87. Müller, M.; Öztürk, E.; Arlov, Ø.; Gatenholm, P.; Zenobi-Wong, M. Alginate sulfate-nanocellulose bioinks for cartilage bioprinting applications. Ann. Biomed. Eng. 2017, 45, 210-223. [CrossRef] [PubMed]

88. Nguyen, D.; Hägg, D.A.; Forsman, A.; Ekholm, J.; Nimkingratana, P.; Brantsing, C.; Kalogeropoulos, T.; Zaunz, S.; Concaro, S.; Brittberg, M.; et al. Cartilage tissue engineering by the 3D bioprinting of iPS cells in a nanocellulose/alginate bioink. Sci Rep. 2017, 7, 658. [CrossRef] [PubMed]

89. Wang, X.; Ao, Q.; Tian, X.; Fan, J.; Tong, H.; Hou, W.; Bai, S. Gelatin-based hydrogels for organ 3D bioprinting. Polymers 2017, 9, 401. [CrossRef]

90. Madl, C.M.; Katz, L.M.; Heilshorn, S.C. Bio-orthogonally crosslinked, engineered protein hydrogels with tunable mechanics and biochemistry for cell encapsulation. Adv. Funct. Mater. 2016, 26, 3612-3620. [CrossRef] [PubMed]

91. Zhao, X.; Liu, L.; Wang, J.; Xu, Y.; Zhang, W.; Khang, G.; Wang, X. In vitro vascularization of a combined system based on a 3D printing technique. J. Tissue Eng. Regen. Med. 2016, 10, 833-842. [CrossRef] [PubMed]

92. Kang, H.-W.; Sang, J.L.; Ko, I.K.; Kengla, C.; Yoo, J.J.; Atala, A. A 3D bioprinting system to produce human-scale tissue constructs with structural integrity. Nat. Biotechnol. 2016, 34, 312-319. [CrossRef] [PubMed]

93. Kolesky, D.B.; Homan, K.A.; Skylarscott, M.A.; Lewis, J.A. Three-dimensional bioprinting of thick vascularized tissues. Proc. Natl. Acad. Sci. USA 2016, 113, 3179-3184. [CrossRef] [PubMed]

94. Grigore, A.; Sarker, B.; Fabry, B.; Boccaccini, A.R.; Detsch, R. Behavior of encapsulated MG-63 cells in RGD and gelatine-modified alginate hydrogels. Tissue Eng. Part A. 2014, 20, 2140-2150. [CrossRef] [PubMed]

95. Van Den Bulcke, A.I.; Bogdanov, B.; De Rooze, N.; Schacht, E.H.; Cornelissen, M.; Berghmans, H. Structural and rheological properties of methacrylamide modified gelatin hydrogels. Biomacromolecules 2000, 1, 31-38. [CrossRef] [PubMed]

96. Wang, X.; Liu, C. 3D bioprinting of adipose-derived stem cells for organ manufacturing. In Enabling Cutting Edge Technology for Regenerative Medicine, Khang, G., Ed.; Springer: Singapore, 2018; pp. 1-16.

97. Yan, Y.; Wang, X.; Pan, Y.; Liu, H.; Cheng, J.; Xiong, Z.; Lin, F.; Wu, R.; Zhang, R.; Lu, Q. Fabrication of viable tissue-engineered constructs with 3D cell-assembly technique. Biomaterials 2005, 26, 5864-5871. [CrossRef] [PubMed]

98. Wang, X.; Yan, Y.; Pan, Y.; Xiong, Z.; Liu, H.; Cheng, J.; Liu, F.; Lin, F.; Wu, R.; Zhang, R.; et al. Generation of three-dimensional hepatocyte/gelatin structures with rapid prototyping system. Tissue Eng. 2006, 12, 83-90. [CrossRef] [PubMed]

99. Xu, W.; Wang, X.; Yan, Y.; Zheng, W.; Xiong, Z.; Lin, F.; Wu, R.; Zhang, R. Rapid prototyping three-dimensional cell/gelatin/fibrinogen constructs for medical regeneration. J. Bioact. Compat. Polym. 2007, 22, 363-377. [CrossRef] 
100. Zhang, T.; Yan, Y.; Wang, X.; Xiong, Z.; Lin, F.; Wu, R.; Zhang, R. Three-dimensional gelatin and gelatin/hyaluronan hydrogel structures for traumatic brain injury. J. Bioact. Compat. Polym. 2007, 22, 19-29. [CrossRef]

101. Xu, W.; Wang, X.; Yan, Y.; Zhang, R. A polyurethane-gelatin hybrid construct for the manufacturing of implantable bioartificial livers. J. Bioact. Compat. Polym. 2008, 23, 409-422. [CrossRef]

102. He, K.; Wang, X. Rapid prototyping of tubular polyurethane and cell/hydrogel constructs. J. Bioact. Compat. Polym. 2011, 26, 363-374.

103. Skardal, A.; Zhang, J.; McCoard, L.; Xu, X. Photocrosslinkable hyaluronan-gelatin hydrogels for two-step bioprinting. Tissue Eng. A 2010, 16, 2675-2685. [CrossRef] [PubMed]

104. Wüst, S.; Godla, M.E.; Müller, R.; Hofmann, S. Tunable hydrogel composite with two-step processing in combination with innovative hardware upgrade for cell-based three-dimensional bioprinting. Acta Biomater. 2014, 10, 630-640. [CrossRef] [PubMed]

105. Hakam, M.S.; Imani, R.; Abolfathi, N.; Fakhrzadeh, H.; Sharifi, A.M. Evaluation of fibrin-gelatin hydrogel as biopaper for application in skin bioprinting: An in-vitro study. Biomed. Mater. Eng. 2016, 27, 669-682. [CrossRef] [PubMed]

106. Heris, H.K.; Rahmat, M.; Mongeau, L. Characterization of a hierarchical network of hyaluronic acid/gelatin composite for use as a smart injectable biomaterial. Macromol. Biosci. 2012, 12, 202-210. [CrossRef] [PubMed]

107. Skardal, A.; Devarasetty, M.; Kang, H.W.; Seol, Y.J.; Forsythe, S.D.; Bishop, C.; Shupe, T.; Soker, S.; Atala, A. Bioprinting cellularized constructs using a tissue-specific hydrogel bioink. J. Vis. Exp. 2016, 21, e53606. [CrossRef] [PubMed]

108. Hemshekhar, M.; Thushara, R.M.; Chandranayaka, S.; Sherman, L.S.; Kemparaju, K.; Girish, K.S. Emerging roles of hyaluronic acid bioscaffolds in tissue engineering and regenerative medicine. Int. J. Biol. Macromol. 2016, 86, 917-928. [CrossRef] [PubMed]

109. Park, Y.D.; Tirelli, N.; Hubbell, J.A. Photopolymerized hyaluronic acid-based hydrogels and interpenetrating networks. Biomaterials 2003, 24, 893-900. [CrossRef]

110. Abbadessa, A.; Mouser, V.H.; Blokzijl, M.M.; Gawlitta, D.; Dhert, W.J.; Hennink, W.E.; Malda, J.; Vermonden, T. A synthetic thermosensitive hydrogel for cartilage bioprinting and its biofunctionalization with polysaccharides. Biomacromolecules 2016, 17, 2137-2147. [CrossRef] [PubMed]

111. Camci-Unal, G.; Cuttica, D.; Annabi, N.; Demarchi, D.; Khademhosseini, A. Synthesis and characterization of hybrid hyaluronic acid-gelatin hydrogels. Biomacromolecules 2013, 14, 1085-1092. [CrossRef] [PubMed]

112. Duan, B.; Kapetanovic, E.; Hockaday, L.A.; Butcher, J.T. Three-dimensional printed trileaflet valve conduits using biological hydrogels and human valve interstitial cells. Acta Biomater. 2014, 10, 1836-1846. [CrossRef] [PubMed]

113. Helary, C.; Bataille, I.; Abed, A.; Illoul, C.; Anglo, A.; Louedec, L.; Letourneur, D.; Meddahi-Pellé, A.; Giraud-Guille, M.M. Concentrated collagen hydrogels as dermal substitutes. Biomaterials 2010, 31, 481-490. [CrossRef] [PubMed]

114. Nagel, T.; Kelly, D.J. The composition of engineered cartilage at the time of implantation determines the likelihood of regenerating tissue with a normal collagen architecture. Tissue Eng. Part A 2013, 19, 824-833. [CrossRef] [PubMed]

115. Weadock, K.S.; Miller, E.J.; Keuffel, E.L.; Dunnl, M.G. Effect of physical crosslinking methods on collagen-fiber durability in proteolytic solutions. J. Biomed. Mater. Res. 1996, 32, 221-226. [CrossRef]

116. Ren, X.; Wang, F.; Chen, C.; Gong, X.; Yin, L.; Yang, L. Engineering zonal cartilage through bioprinting collagen type II hydrogel constructs with biomimetic chondrocyte density gradient. BMC Musculoskelet. Disord. 2016, 17, 301. [CrossRef] [PubMed]

117. Chen, C.; Zhao, M.L.; Zhang, R.K.; Lu, G.; Zhao, C.Y.; Fu, F.; Sun, H.T.; Zhang, S.; Tu, Y.; Li, X.H. Collagen/heparin sulfate scaffolds fabricated by a 3D bioprinter improved mechanical properties and neurological function after spinal cord injury in rats. J. Biomed. Mater. Res. A 2017, 105, 1324-1332. [CrossRef] [PubMed]

118. Cui, T.; Yan, Y.; Zhang, R.; Liu, L.; Xu, W.; Wang, X. Rapid prototyping of a double layer polyurethane-collagen conduit for peripheral nerve regeneration. Tissue Eng. Part C 2009, 15, 1-9. [CrossRef] [PubMed]

119. Cui, T.; Wang, X.; Yan, Y.; Zhang, R. Rapid prototyping a new polyurethane-collagen conduit and its Schwann cell compatibility. J. Bioact. Compat. Polym. 2009, 24, 5-17. [CrossRef] 
120. Wang, X.; Cui, T.; Yan, Y.; Zhang, R. Peroneal nerve regeneration along a new polyurethane-collagen guide conduit. J. Bioact. Compat. Polym. 2009, 24, 109-127. [CrossRef]

121. Mosesson, M.W. Fibrinogen and fibrin structure and functions. J. Thromb. Haemost. 2005, 3, $1894-1904$. [CrossRef] [PubMed]

122. Wang, X.; Mäkitie, A.A.; Paloheimo, K.-S.; Tuomi, J.; Paloheimo, M.; Sui, S.; Zhang, Q. Characterization of a PLGA sandwiched cell/fibrin tubular construct and induction of the adipose derived stem cells into smooth muscle cells. Mater. Sci. Eng. C 2011, 31, 801-808. [CrossRef]

123. Wang, X.; Sui, S.; Liu, C. Optimizing the step by step forming processes for fabricating a PLGA sandwiched cell/hydrogel construct. J. Appl. Polym. Sci. 2011, 120, 1199-1207. [CrossRef]

124. Wang, X.; Sui, S. Pulsatile culture of a PLGA sandwiched cell/hydrogel construct fabricated using a step by step mold/extraction method. Artif. Organs 2011, 35, 645-655. [CrossRef] [PubMed]

125. Gasperini, L.; Mano, J.F.; Reis, R.L. Natural polymers for the microencapsulation of cells. J. R. Soc. Interface 2014, 11, 20140817. [CrossRef] [PubMed]

126. Rowe, S.L.; Lee, S.; Stegemann, J.P. Influence of thrombin concentration on the mechanical and morphological properties of cell-seeded fibrin hydrogels. Acta Biomater. 2007, 3, 59-67. [CrossRef] [PubMed]

127. Wang, X. 3D printing of tissue/organ analogues for regenerative medicine. In Handbook of Intelligent Scaffolds for Regenerative Medicine, 2nd ed.; Pan Stanford Publishing: Palo Alto, CA, USA, 2016; pp. 557-570.

128. Wang, X. Spatial effects of stem cell engagement in 3D printing constructs. J. Stem Cells Res. Rev. Rep. 2014, $1,5-9$.

129. Wang, X.; Ao, Q.; Tian, X.; Fan, J.; Wei, Y.; Hou, W.; Tong, H.; Bai, S. 3D bioprinting technologies for hard tissue and organ engineering. Materials 2016, 9, 802. [CrossRef] [PubMed]

130. Wang, X.; Wang, J. Vascularization and adipogenesis of a spindle hierarchical adipose-derived stem cell/collagen/ alginate-PLGA construct for breast manufacturing. IJITEE 2015, 4, 1-8.

131. Skardal, A.; Mack, D.; Kapetanovic, E.; Atala, A.; Jackson, J.D.; Yoo, J.; Soker, S. Bioprinted amniotic fluid-derived stem cells accelerate healing of large skin wounds. Stem Cells Transl. Med. 2012, 1, 792-802. [CrossRef] [PubMed]

132. Wang, X.; Ma, J.; Wang, Y.; He, B. Structural characterization of phosphorylated chitosan and their applications as effective additives of calcium phosphate cements. Biomaterials 2001, 22, 2247-2255. [CrossRef]

133. Wang, X.; Ma, J.; Wang, Y.; He, B. Bone repair in radii and tibias of rabbits with phosphorylated chitosan reinforced calcium phosphate cements. Biomaterials 2002, 23, 4167-4176. [CrossRef]

134. Wang, X.; Ma, J.; Feng, Q.; Cui, F. Skeletal repair in of rabbits with calcium phosphate cements incorporated phosphorylated chitin reinforced. Biomaterials 2002, 23, 4591-4600. [CrossRef]

135. Wang, X.; Li, D.; Wang, W.; Feng, Q.; Cui, F.; Xu, Y.; Song, X. Covalent immobilization of chitosan and heparin on PLGA surface. Int. J. Macromol. 2003, 33, 95-100. [CrossRef]

136. Wang, X.; Ma, J.; Feng, Q.; Cui, F. The effects of S-chitosan on the physical properties of calcium phosphate cements. J. Bioact. Compat. Polym. 2003, 18, 45-57. [CrossRef]

137. Wang, X.; Ma, J.; Feng, Q.; Cui, F. In vivo testing of S-chitosan enhanced calcium phosphate cements. J. Bioact. Compat. Polym. 2003, 18, 259-271. [CrossRef]

138. Wang, X.; Li, D.; Wang, W.; Feng, Q.; Cui, F.; Xu, Y.; Song, X.; van der Werf, M. Crosslinked collagen/chitosan matrices for artificial livers. Biomaterials 2003, 24, 3213-3220. [CrossRef]

139. Ma, L.; Gao, C.; Mao, Z.; Zhou, J.; Shen, J.; Hu, X.; Han, C. Collagen/chitosan porous scaffolds with improved biostability for skin tissue engineering. Biomaterials 2003, 24, 4833-4841. [CrossRef]

140. Fu, X.T.; Kim, S.M. Agarase: Review of major sources, categories, purification method, enzyme characteristics and applications. Mar. Drugs 2010, 8, 200-218. [CrossRef] [PubMed]

141. Panwar, A.; Tan, L.P. Current status of bioinks for micro-extrusion-based 3D bioprinting. Molecules 2016, 21, 685. [CrossRef] [PubMed]

142. Awad, H.A.; Wickham, M.Q.; Leddy, H.A.; Gimble, J.M.; Guilak, F. Chondrogenic differentiation of adipose-derived adult stem cells in agarose, alginate, and gelatin scaffolds. Biomaterials 2004, 25, 3211-3222. [CrossRef] [PubMed]

143. Fan, R.; Piou, M.; Darling, E.; Cormier, D.; Sun, J.; Wan, J. Bio-printing cell-laden matrigel-agarose constructs. J. Biomater. Appl. 2016, 31, 684-692. [CrossRef] [PubMed]

144. Chen, R.N.; Ho, H.O.; Tsai, Y.T.; Sheu, M.T. Process development of an acellular dermal matrix (ADM) for biomedical applications. Biomaterials 2004, 25, 2679-2686. [CrossRef] [PubMed] 
145. Freytes, D.O.; Martin, J.; Velankar, S.S.; Lee, A.S.; Badylak, S.F. Preparation and rheological characterization of a gel form of the porcine urinary bladder matrix. Biomaterials 2008, 29, 1630-1637. [CrossRef] [PubMed]

146. Pati, F.; Jang, J.; Ha, D.-H.; Kim, D.H.; Cho, D.W. Printing three-dimensional tissue analogues with decellularized extracellular matrix bioink. Nat. Commun. 2014, 5, 3935. [CrossRef] [PubMed]

147. Sellaro, T.L.; Ranade, A.; Faulk, D.M.; McCabe, G.P.; Dorko, K.; Badylak, S.F.; Strom, S.C. Maintenance of human hepatocyte function in vitro by liver-derived extracellular matrix gels. Tissue Eng. Part A 2010, 16, 1075-1082. [CrossRef] [PubMed]

148. Wong, S.Y.; Tay, C.Y.; Wen, F.; Venkatraman, S.S.; Tan, L.P. Engineered polymeric biomaterials for tissue engineering. Curr. Tissue Eng. 2012, 1, 41-53. [CrossRef]

149. Wang, X.; Rijff, B.L.; Khang, G. A building block approach into 3D printing a multi-channel organ regenerative scaffold. J. Tissue Eng. Regen. Med. 2017, 11, 1403-1411. [CrossRef] [PubMed]

150. Xu, Y.; Wang, X. Fluid and cell behaviors along a 3D printed alginate/gelatin/fibrin channel. Biotechnol. Bioeng. 2015, 112, 1683-1695. [CrossRef] [PubMed]

151. Wang, X. Overview on biocompatibilities of implantable biomaterials. In Advances in Biomaterials Science and Biomedical Applications in Biomedicine; Lazinica, R., Ed.; In Tech: Rijeka, Croatia, 2013; pp. 111-155.

152. Liu, L.; Wang, X. Creation of a vascular system for complex organ manufacturing. Int. J. Bioprint. 2015, 1, 77-86.

153. Liu, L.; Wang, X. Artificial blood vessels and vascular systems. In Organ Manufacturing; Wang, X., Ed.; Nova Science Publishers Inc.: Hauppauge, NY, USA, 2015; pp. 75-99.

154. Wang, X.; Liu, C. Fibrin hydrogels for endothelialized liver tissue engineering with a predesigned vascular network. Polymers 2018, 10, 1084. [CrossRef]

155. Wang, X. Bioartificial organ manufacturing technologies. Cell Transplant 2018, in press.

156. Guarino, V.; Gloria, A.; Raucci, M.G.; Santis, R.D.; Ambrosio, L. Bio-inspired composite and cell instructive platforms for bone regeneration. Int. Mater. Rev. 2012, 57, 256-275. [CrossRef]

157. Reitmaier, S.; Shirazi-Adl, A.; Bashkuev, M.; Wilke, H.-J.; Gloria, A.; Schmidt, H. In vitro and in silico investigations of disc nucleus replacement. J. R. Soc. Interface 2012, 9, 1869-1879. [CrossRef] [PubMed]

(C) 2018 by the authors. Licensee MDPI, Basel, Switzerland. This article is an open access article distributed under the terms and conditions of the Creative Commons Attribution (CC BY) license (http:/ / creativecommons.org/licenses/by/4.0/). 